\title{
Volcanic air pollution and human health: recent advances and future directions
}

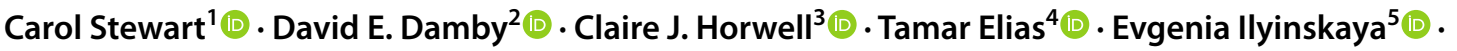

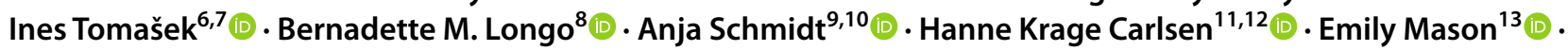

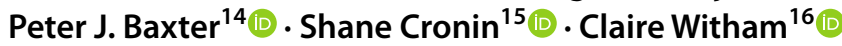

Received: 24 July 2021 / Accepted: 2 November 2021 / Published online: 21 December 2021

(c) The Author(s) 2021

\begin{abstract}
Volcanic air pollution from both explosive and effusive activity can affect large populations as far as thousands of kilometers away from the source, for days to decades or even centuries. Here, we summarize key advances and prospects in the assessment of health hazards, effects, risk, and management. Recent advances include standardized ash assessment methods to characterize the multiple physicochemical characteristics that might influence toxicity; the rise of community-based air quality monitoring networks using low-cost gas and particulate sensors; the development of forecasting methods for ground-level concentrations and associated public advisories; the development of risk and impact assessment methods to explore health consequences of future eruptions; and the development of evidence-based, locally specific measures for health protection. However, it remains problematic that the health effects of many major and sometimes long-duration eruptions near large populations have gone completely unmonitored. Similarly, effects of prolonged degassing on exposed populations have received very little attention relative to explosive eruptions. Furthermore, very few studies have longitudinally followed populations chronically exposed to volcanic emissions; thus, knowledge gaps remain about whether chronic exposures can trigger development of potentially fatal diseases. Instigating such studies will be facilitated by continued co-development of standardized protocols, supporting local study teams and procuring equipment, funding, and ethical permissions. Relationship building between visiting researchers and host country academic, observatory, and agency partners is vital and can, in turn, support the effective communication of health impacts of volcanic air pollution to populations, health practitioners, and emergency managers.
\end{abstract}

Keywords Volcanic emissions · Air pollution · Review $\cdot$ Health effects $\cdot$ Health hazard assessment $\cdot$ Risk management

\section{Introduction}

Globally, over a billion people are estimated to live within $100 \mathrm{~km}$ of an active volcano (Freire et al. 2019). Volcanic eruptions may cause injuries and fatalities via a range of hazardous phenomena (e.g., pyroclastic density currents,

This paper constitutes part of a topical collection:

Looking Backwards and Forwards in Volcanology:

A Collection of Perspectives on the Trajectory of a Science

Editorial responsibility: K.V. Cashman; Deputy Executive

Editor: L. Pioli

Carol Stewart

c.stewart1@ massey.ac.nz

Extended author information available on the last page of the article ballistics, lahars, lava flows, and localized accumulations or flows of asphyxiant gases such as $\mathrm{CO}_{2}$ and $\mathrm{H}_{2} \mathrm{~S}$ ), affecting communities within tens of kilometers of the vent (Brown et al. 2017). Eruptions may also displace large numbers of people temporarily or permanently (Cuthbertson et al. 2020) with cascading health and social impacts including disease outbreaks due to overcrowding, food insecurity, mental health issues, and violence (Connell and Lutkehaus 2017). Airborne volcanic emissions, often referred to as "volcanic air pollution" (Tam et al. 2016; Crawford et al. 2021), can also present chronic, far-reaching hazards which may have harmful and long-lasting effects on populations across large geographic areas (Oppenheimer et al. 2003). Here, we address the state of knowledge regarding volcanic air pollution and health. This includes a discussion of hazard assessment methods, a summary of reported human health effects, a review of risk assessment, population preparedness and 


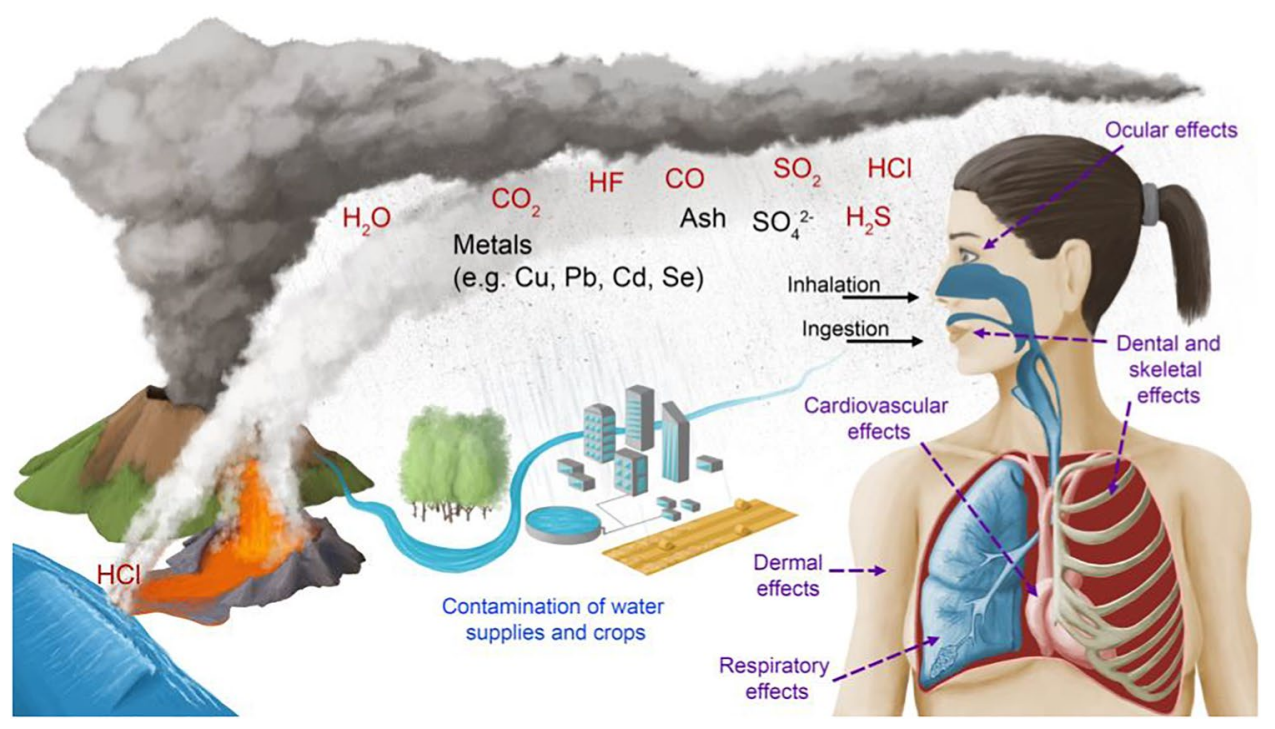

Fig. 1 Volcanic emission components, exposure pathways, and categories of human health effects. Gaseous species are shown in red and particulate species in black. The upper plume represents airborne emissions from an explosive eruption, while the lower plume is generated by effusive activity. A steamy "laze" plume, created by interaction of molten lava with seawater, contains hydrochloric acid, vari-

protection practices, and a discussion of emerging themes and future directions.

\section{Volcanic emission hazards}

Airborne volcanic emissions comprise variable mixtures of silicate ash, gases $\left(\mathrm{H}_{2} \mathrm{O}, \mathrm{CO}_{2}, \mathrm{SO}_{2}, \mathrm{H}_{2} \mathrm{~S}, \mathrm{CO}, \mathrm{HF}\right.$, and $\left.\mathrm{HCl}\right)$, volatile metal vapors, and sulfate aerosol, formed through $\mathrm{SO}_{2}$ gas-to-particle conversion (Fig. 1; Oppenheimer et al. 2003). Ash can be generated during a variety of eruptive processes and can contain substantial amounts of respirablesized particles $(<4 \mu \mathrm{m}$ diameter $)$ that can penetrate into the lungs (Horwell 2007). The physical and chemical properties of ash can vary significantly across eruptions and with distance (Jenkins et al. 2015). As volcanic gases cool and react in the atmosphere, they may condense into particles and/or adsorb to ash surfaces (Oppenheimer et al. 2003). Volcanic aerosol particles formed through gas condensation are extremely fine-grained, typically $\sim 0.2-0.5 \mu \mathrm{m}$ in diameter (Mather et al. 2003). Volcanic particulate matter (PM) thus encompasses a heterogeneous mixture of ash PM and acidic sulfate- and metal-bearing aerosol PM. A further airborne hazard is generated when lava flows into seawater, generating a "laze" (lava + haze) plume that contains $\mathrm{HCl}$, volcanic glass fragments, and various metals (Mason et al. 2021; Fig. 1).

Sulfur gases (in particular $\mathrm{SO}_{2}$ ), sulfate aerosol, and ash are the most important airborne hazards for population-scale, ous metals, and volcanic glass particles. Important plume processes include gas to particle conversion and adsorption of gas onto silicate ash surfaces. Contamination of water supplies by volcanogenic fluoride (from gaseous $\mathrm{HF}$ ) is proposed to be the major ingestion pathway leading to human dental and skeletal effects.

longer-term impacts and have been shown to affect air quality locally as well as hundreds to thousands of kilometers from source during large fissure or explosive eruptions (e.g., Schmidt et al. 2011, 2015; de Lima et al. 2012; Durant et al. 2012; Eychenne et al. 2015; Ilyinskaya et al. 2017). Many of the volatile trace elements emitted by volcanoes are classified as metal pollutants by environmental and health protection agencies (e.g., lead, zinc, arsenic, cadmium), ${ }^{1}$ and emission rates can reach levels comparable to anthropogenic fluxes from industrialized countries (Ilyinskaya et al. 2021). Near persistently degassing volcanoes, elevated levels of metals have been reported in air, soils, surface waters, and plants (Delmelle 2003), which are common exposure sources for humans (Prüss-Ustün et al. 2011), especially in areas where communities consume catchment or surface water and locally grown crops. Persistent degassing is also the source of fluoride contamination of water resources close to certain volcanoes, notably Ambrym and Tanna, Vanuatu (Cronin and Sharp 2002; Allibone et al. 2012; Webb et al. 2021). Acidified rainfall from persistent degassing can leach lead from plumbing fittings or roofing materials into roof catchment rainwater tanks (Macomber 2020). Ash deposition into water supplies can raise concentrations of fluoride and other potentially toxic elements (e.g., copper, manganese) as well as elements that impart an unpleasant taste or color to the water (Stewart et al. 2006, 2020).

\footnotetext{
$\overline{1}$ https://uk-air.defra.gov.uk/networks/network-info?view=metals
} 


\section{Hazard and exposure assessment}

In an eruption crisis, it is rare for there to be an immediate assessment of the health impact of exposure to volcanic air pollution. With limited resources, health agencies must prioritize ensuring sanitary conditions for evacuated communities and monitoring these communities for infectious disease outbreaks, as well as dealing with casualties. In lieu of data to directly measure the health impact, the physicochemical characteristics of the emissions, along with exposure concentrations and durations, may be assessed to get a first indication of whether they may be hazardous to human health.

For volcanic ash, characteristics that inform whether ash may cause harm if inhaled or ingested include particle size, particle shape, surface area, and the presence of leachable elements. Additional, specific hazards can vary according to magma composition and eruption dynamics. For lava dome-related or intermediate to felsic explosive ash samples, crystalline silica (quartz and its polymorphs) is important to quantify as it is the mineral of greatest health concern in ash due to its capacity to cause disease in industrial settings (Baxter et al. 1999; Greenberg et al. 2007). For mafic samples, reactive surface iron and associated generation of free radicals, which are implicated in respiratory diseases (Kelly 2003), can be determined (Horwell et al. 2007). Leachate analyses can determine concentrations of readily soluble elements on fresh ash particles relevant to inhalation or ingestion pathways. These methods may require adaptation for ash from hydrothermal system eruptions which typically contain fluoride in slowly soluble forms (Cronin et al. 2014; Stewart et al. 2020). Ash can also scavenge biologically potent organic pollutants from the atmosphere (Tomašek et al. 2021a). Toxicological assays can be used to assess whether the ash can trigger a biological response, which gives an indication of potential pathogenicity for humans (Damby et al. 2016).

The International Volcanic Health Hazard Network $(\text { IVHHN })^{2}$ has developed methods and protocols for rapid, standardized screening of ash samples (Le Blond et al. 2009; Horwell 2007; Horwell et al. 2007; Stewart et al. 2020; Tomašek et al. 2021b), which have been applied during various eruption crises. Table 1 presents post-2000 studies that have determined health-relevant characteristics of ash samples and whether they have used IVHHN methods or not. The major challenges associated with ash characterization relate to timely collection of ash samples, prior capacity building and training in suitable laboratories, funding analyses, and shipping of samples, given that transportation is often disrupted during an eruption. In practice, analyses are rarely completed within the days to weeks over which

\footnotetext{
2 www.ivhhn.org
}

acute exposures may be occurring, so cannot be relied upon to inform decision-making. Thus, in advance of future eruptions, the hazard could be informed by study of archived ash samples from historic eruptions (Hillman et al. 2012; Horwell et al. 2010b, 2017; Damby et al. 2017).

Exposure to volcanic emissions rarely occurs in clean atmospheres, raising concerns about co-exposures of volcanic emissions and existing air pollution, particularly in urban areas. Preliminary work on these combined hazards indicates that the specific mixture may be important, with a heightened pro-inflammatory response (in laboratory in vitro tests) reported for simultaneous exposure to respirable ash and diesel exhaust particles (Tomašek et al. 2016) but not for ash and complete gasoline exhaust (Tomašek et al. 2018).

Real-time monitoring of airborne gas and PM concentrations can be used as a proxy for assessing population exposure during eruptions, for persistent degassing, and for posteruption ash resuspension episodes (Wilson et al. 2011). Indoor and outdoor measurements may be made via fixed monitors or portable sensors. Ambient air quality limits exist for airborne contaminants common to volcanic emissions such as $\mathrm{PM}_{10}, \mathrm{PM}_{2.5}$, and $\mathrm{SO}_{2}$, and monitoring data can be used to help alert both healthy and sensitive populations. However, air quality monitoring equipment is not installed at many volcanic locations, and installing instrumentation following eruption onset can present significant challenges (Felton et al. 2019). This can hinder agencies in making evidence-based decisions on community protection. An additional challenge to characterizing volcanic air pollution is that $\mathrm{SO}_{2}$ and $\mathrm{PM}$ concentrations can vary significantly over short distances and durations (Holland et al. 2020). This issue has received significant attention recently with the introduction of low-cost fixed networks and hand-held, portable sensors that augment higher accuracy but costly regulatory air quality monitoring. These low-cost PM and $\mathrm{SO}_{2}$ sensors perform reasonably well for monitoring volcanic air pollution in communities, as demonstrated during the Kīlauea 2018 eruption (Whitty et al. 2020; Crawford et al. 2021) and in Iceland (Gíslason et al. 2015). Air quality forecast models can complement ambient air monitoring and now play an important role in informing the public about current and predicted levels of volcanic pollution in some locations (Barsotti 2020; Holland et al. 2020).

\section{Assessment of health effects}

Post-2000 clinical and epidemiological studies conducted on communities affected by volcanic emissions are presented in Table 2. Collectively, these studies support pre2000 findings, from studies conducted predominantly at Mount St. Helens, Soufrière Hills, and Sakurajima, that exposures to airborne volcanic emissions can exacerbate 


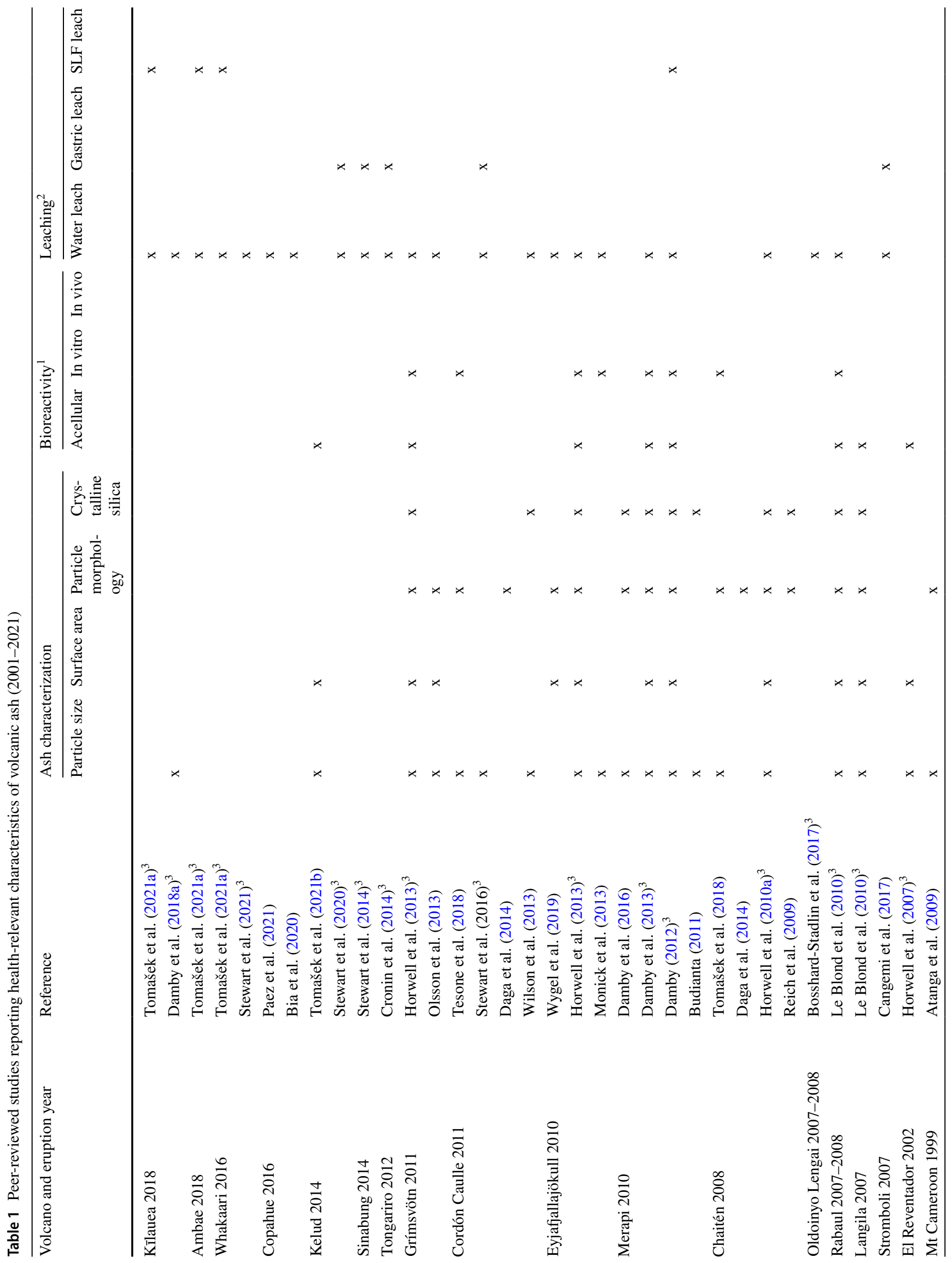




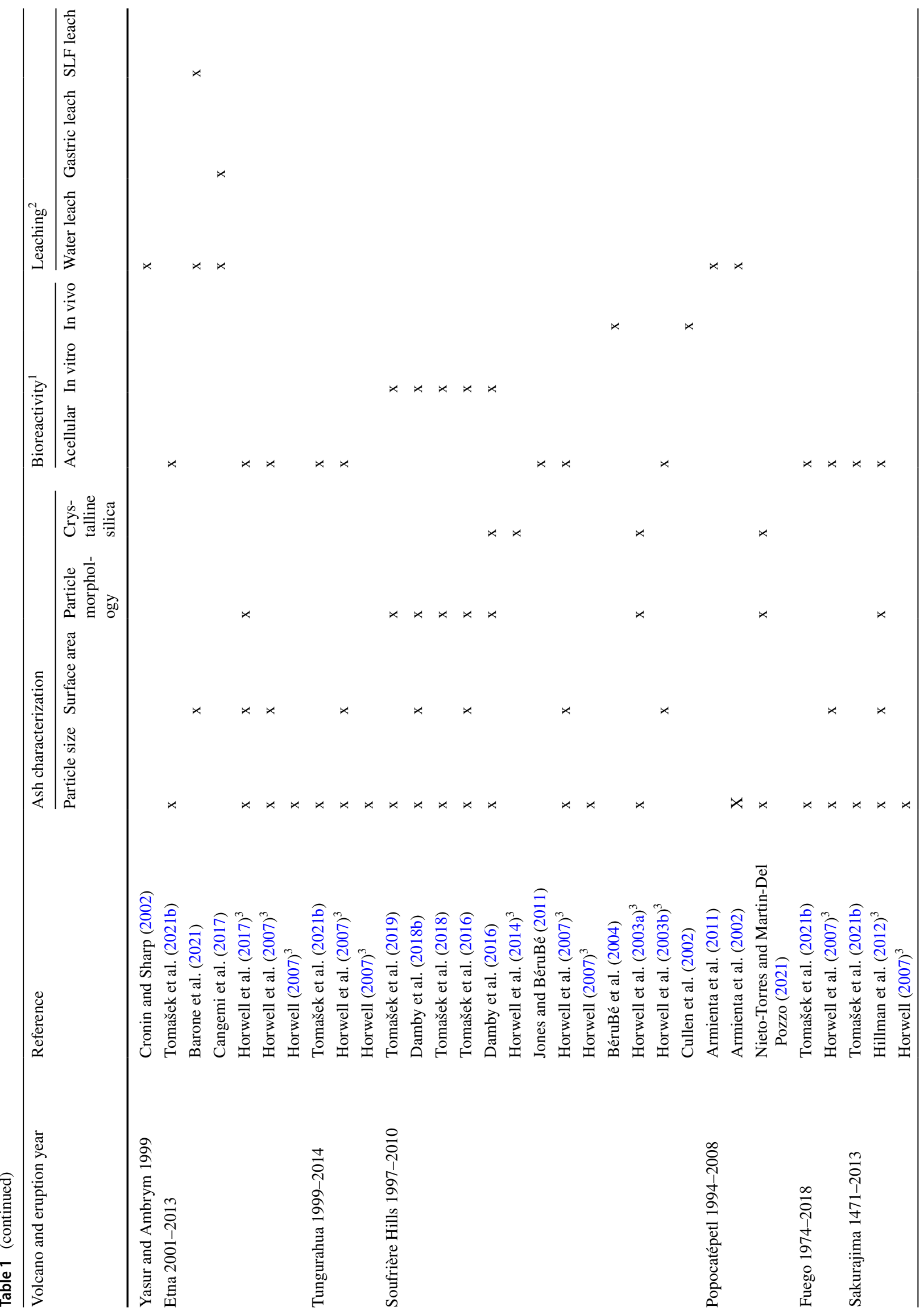




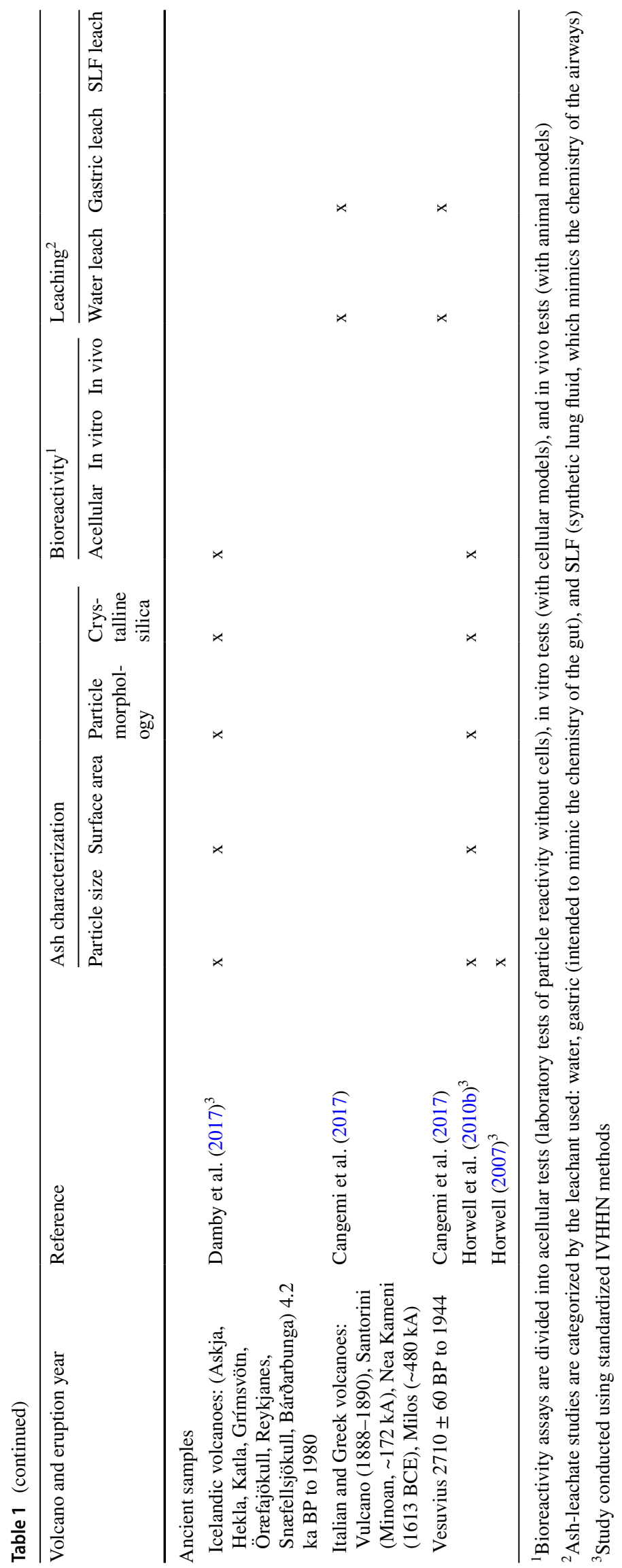




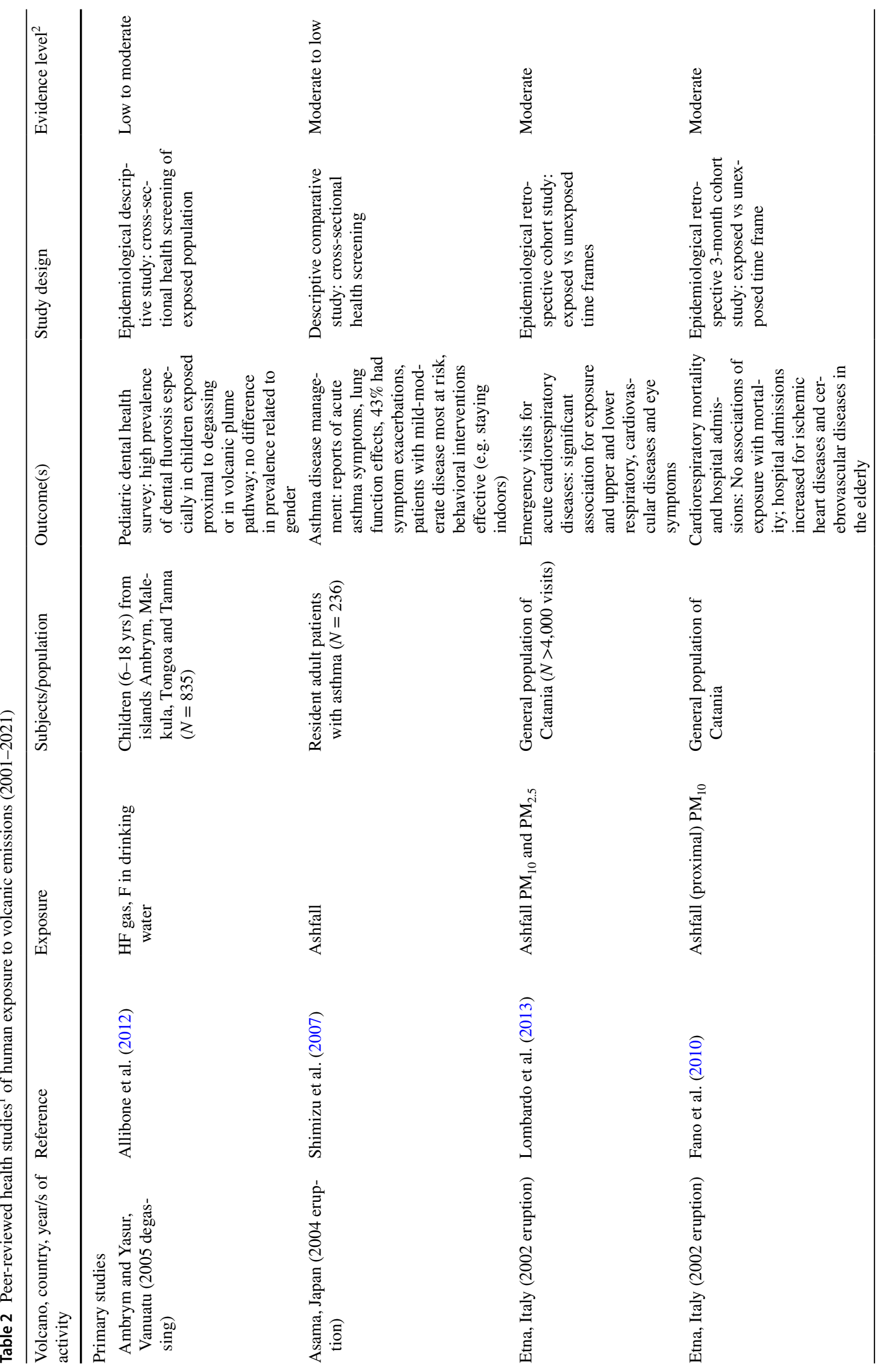




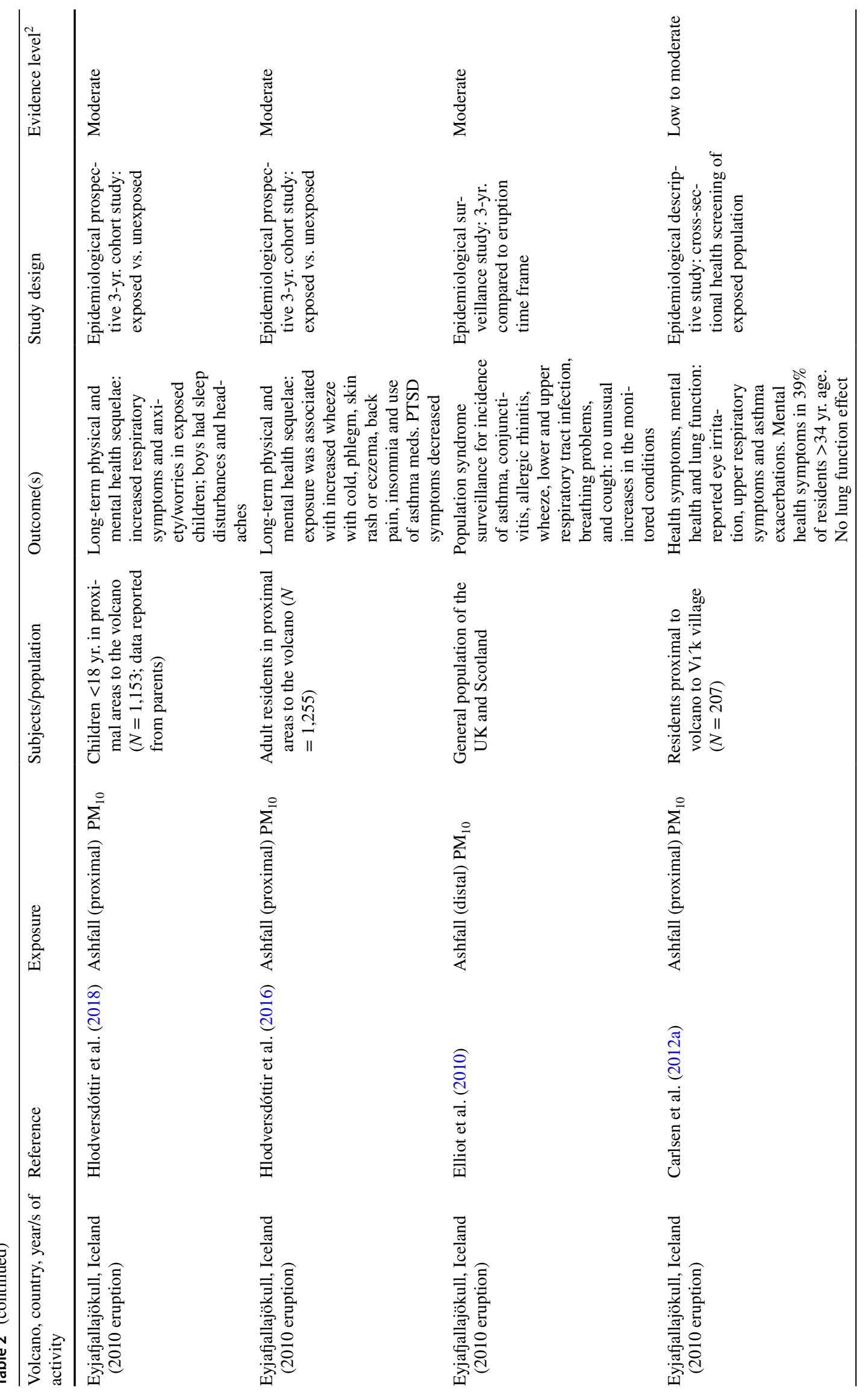




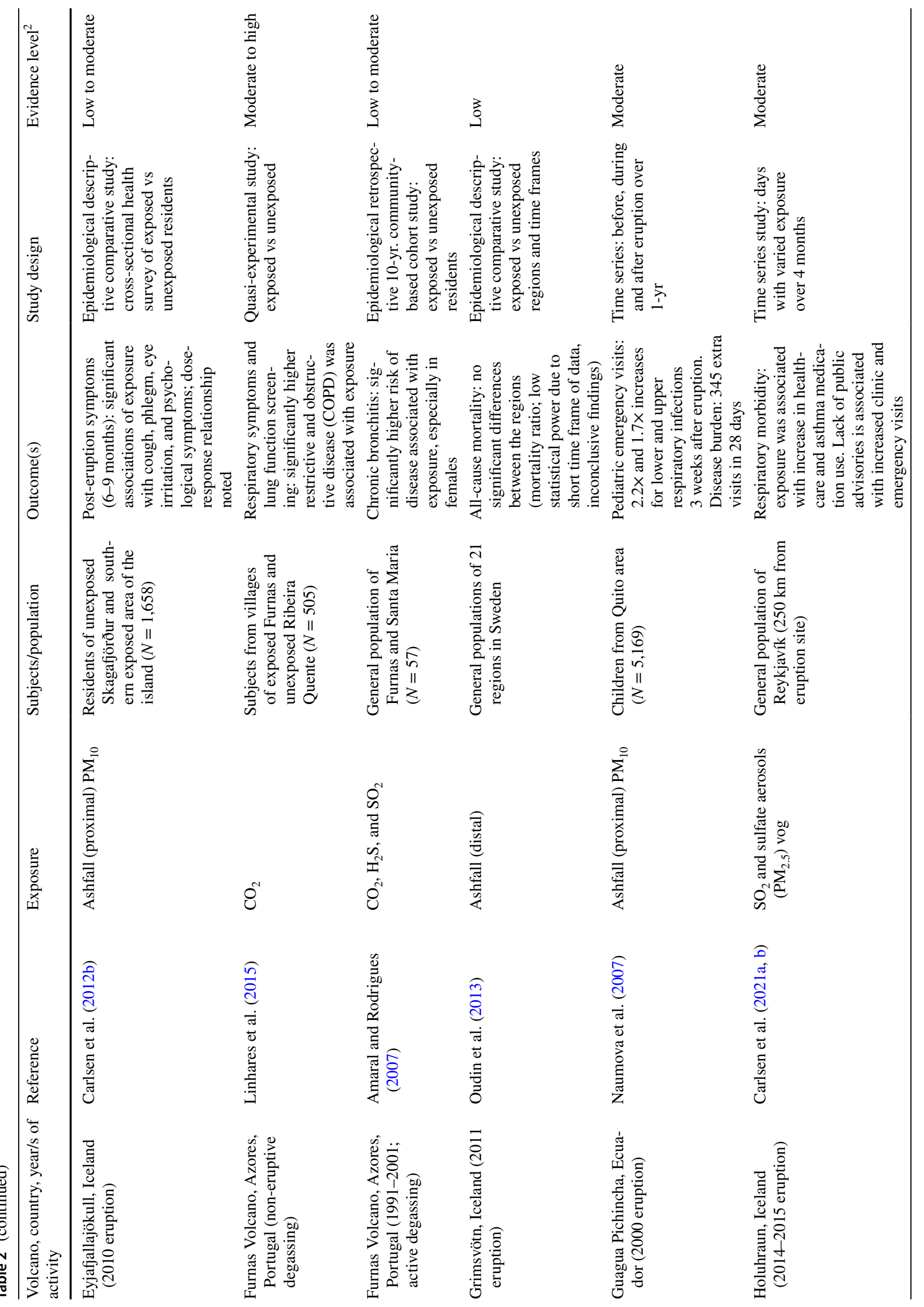




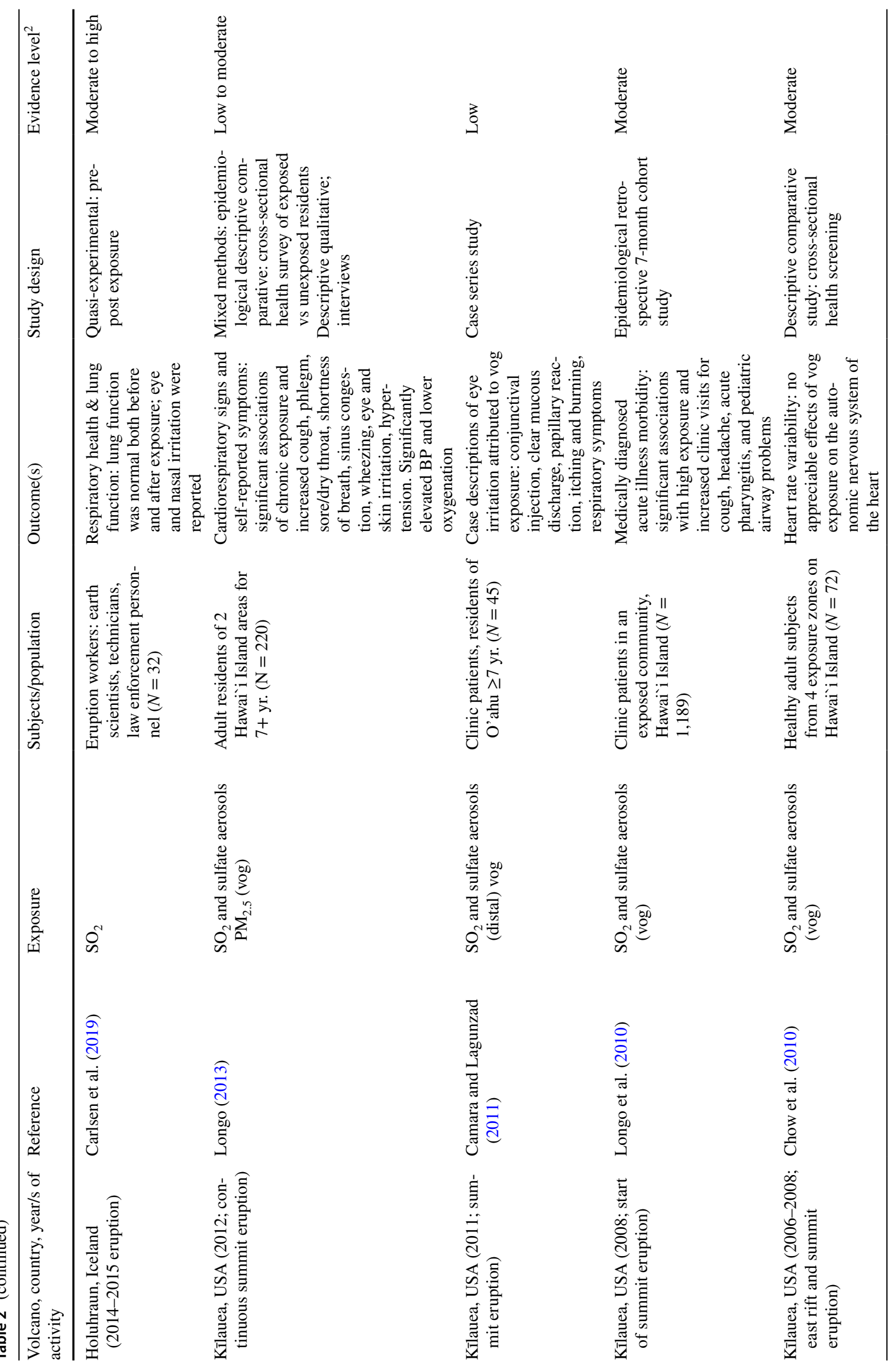




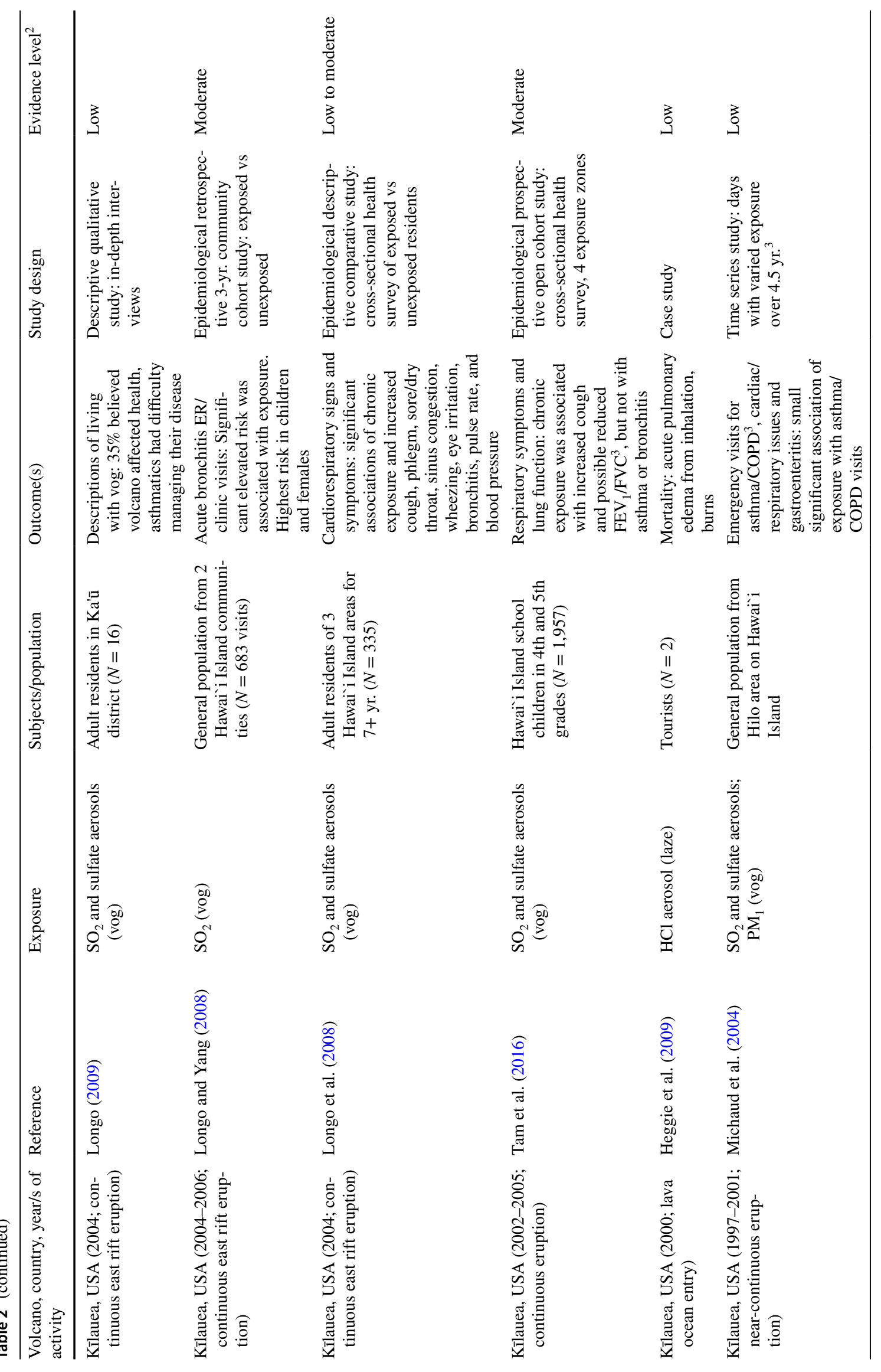




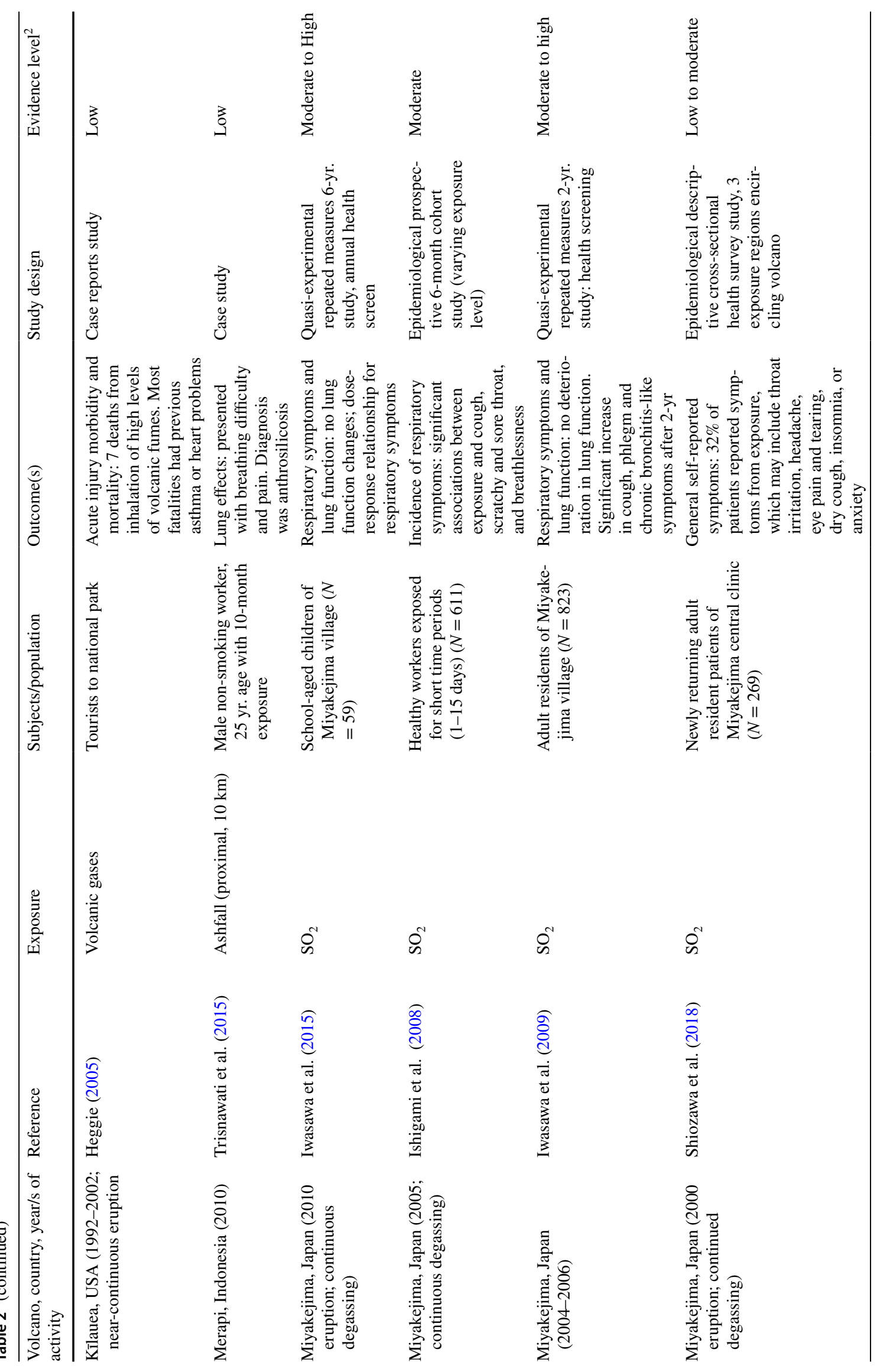




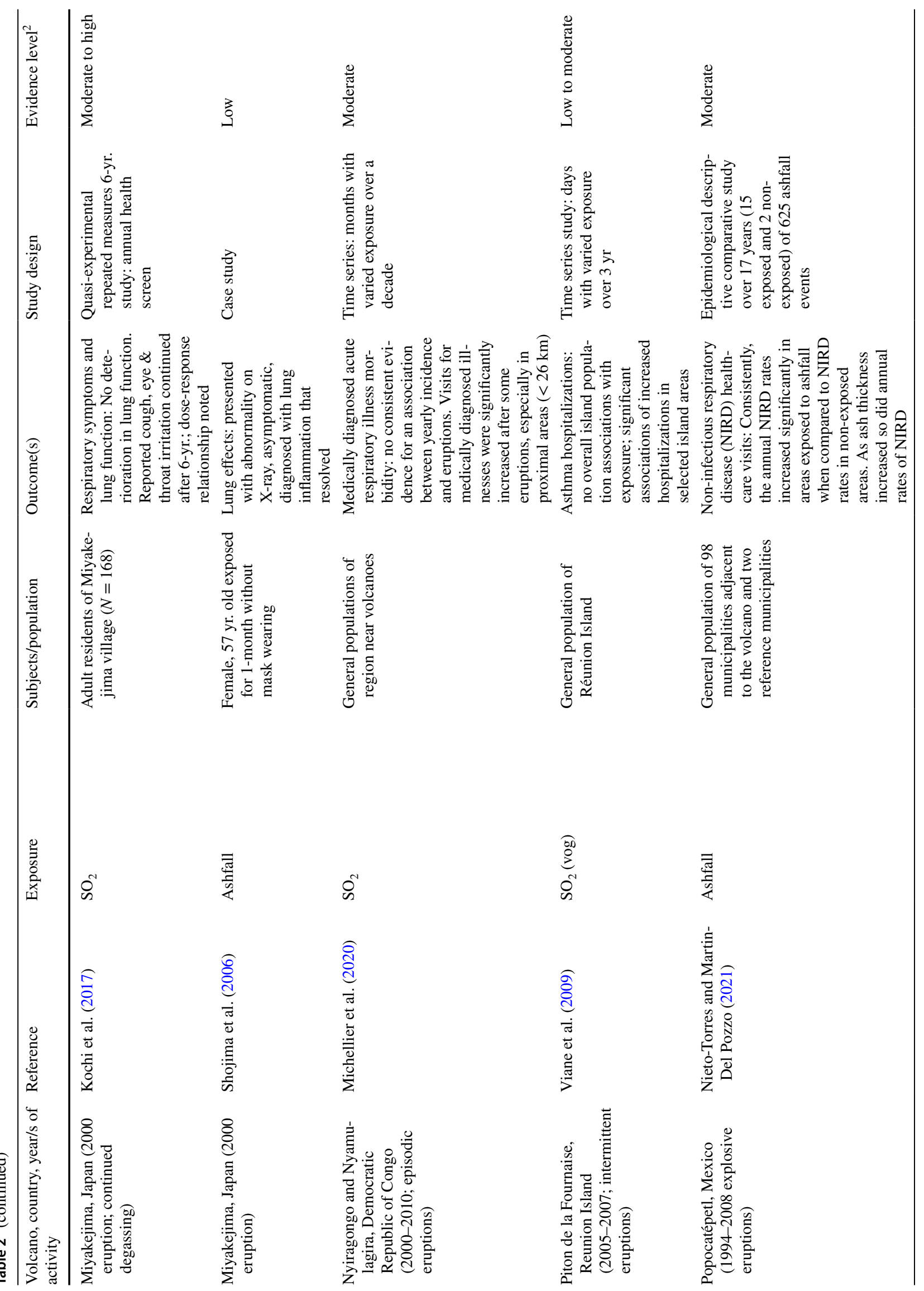




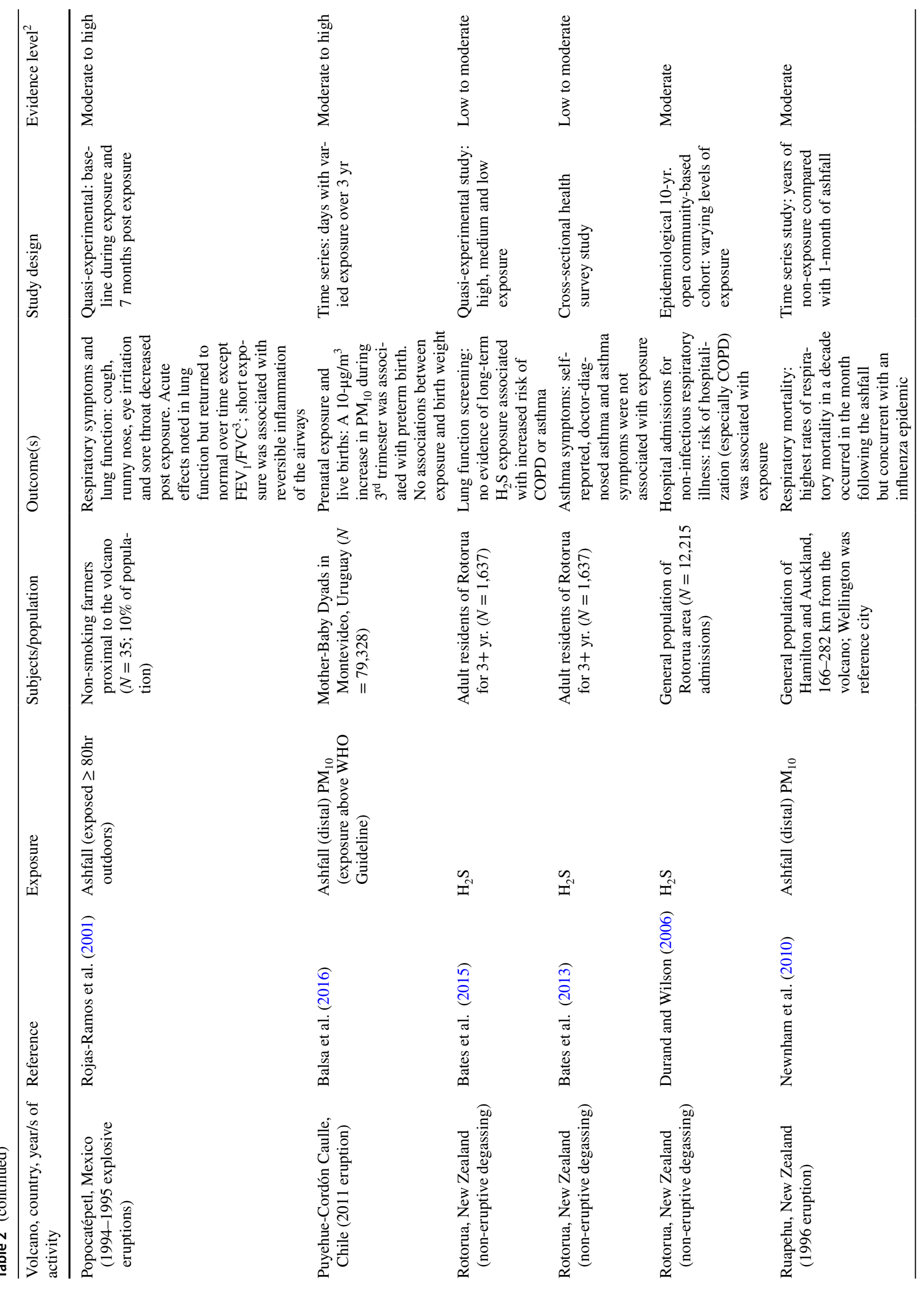




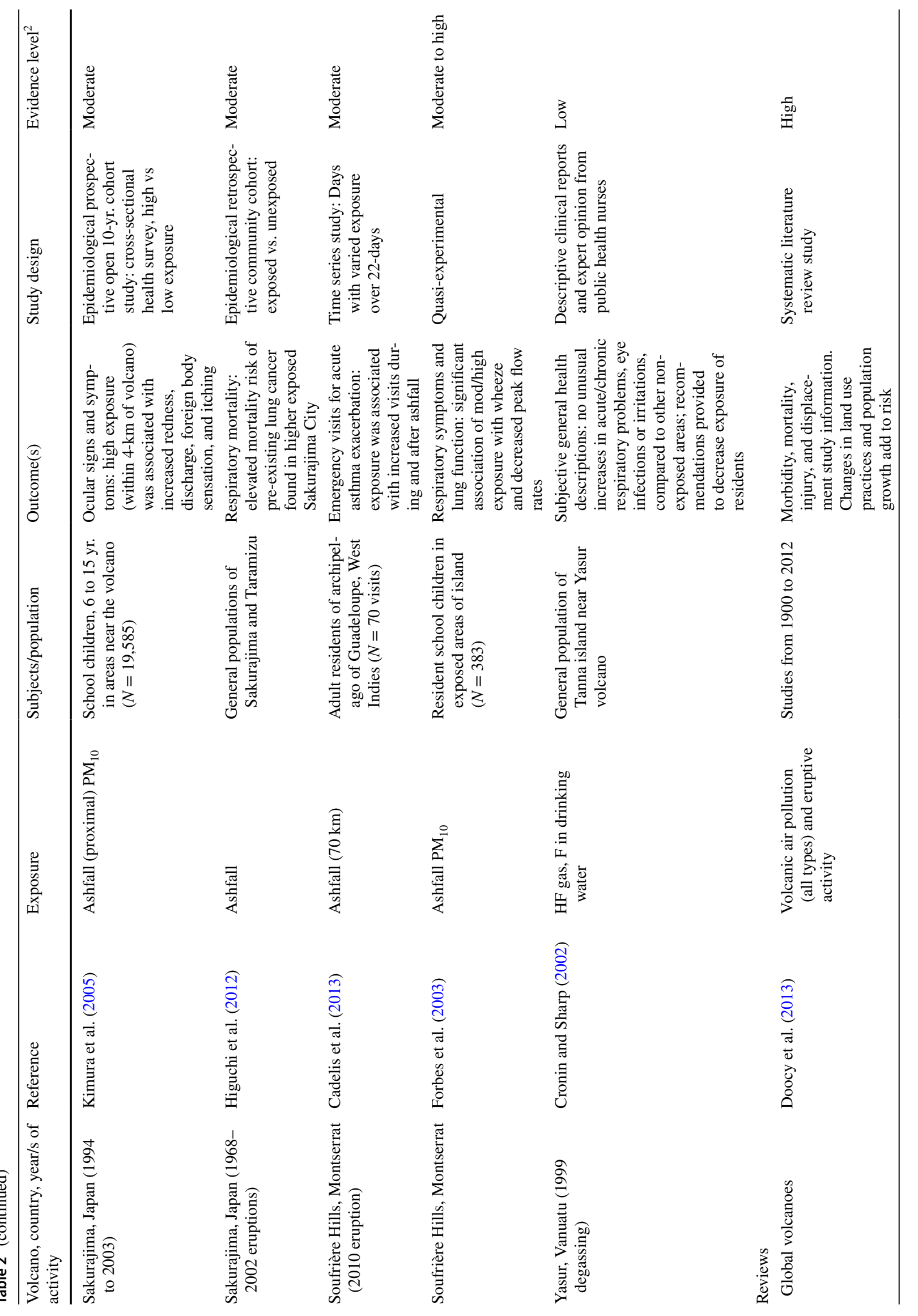




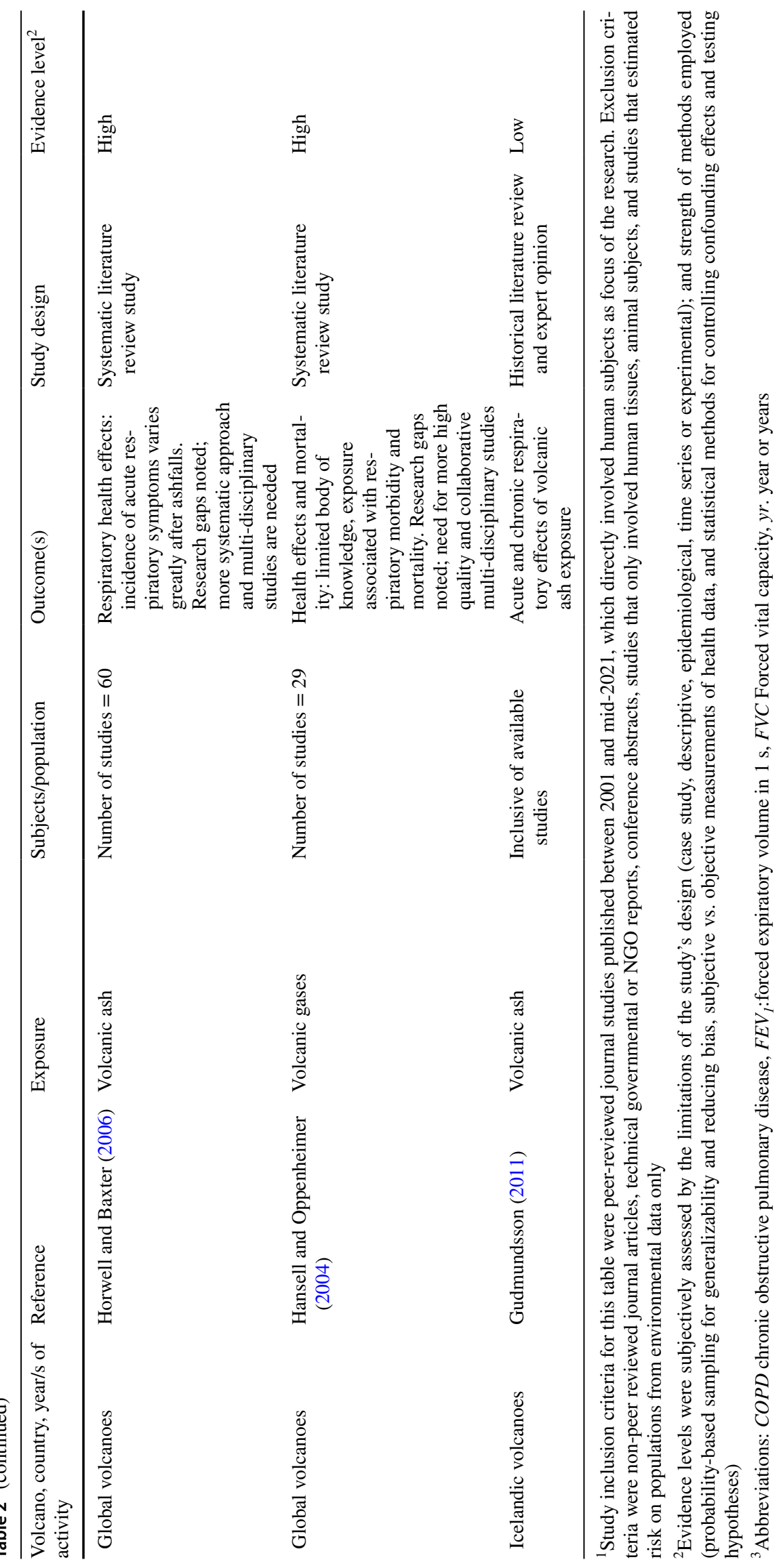


symptoms of pre-existing lung conditions (reviewed in Horwell and Baxter 2006). However, very few of these studies have followed populations longitudinally using the timeframes needed (on the order of decades) for longlatency diseases such as pneumoconioses or cancers to manifest. Further, situations that produce chronic exposure to ash are rare, with the best-documented examples being the 15-year cumulative exposure to ash from Soufrière Hills volcano, Montserrat (Baxter et al. 2014) and the eruption of Sakurajima volcano, Japan, with frequent ash exposures since the 1970s (reviewed by Hillman et al. 2012). Overall, major knowledge gaps remain about whether chronic exposures can trigger development of potentially fatal cardiorespiratory diseases and also whether chronic health effects can result from acute exposures.

Beyond respiratory health, studies of human exposure to volcanic emissions have also reported on ocular, dermal, and cardiovascular effects, gastroenteritis, birth outcomes, dental fluorosis, acute injury, and increased use of healthcare services and medications (summarized in Table 2). Documented instances of human fluorosis associated with active volcanism are rare globally (D'Alessandro 2006; Table 2) but may be under-reported. Mental health has also received attention, but few studies have addressed specific mental health impacts resulting from exposure to volcanic air pollution.

The evidence base is weak on which characteristics of volcanic or other air pollution sources are responsible for the observed negative health outcomes. Routine monitoring does not cover all species of concern (e.g., metal pollutants and aerosol acidity). In the past decade, many air pollution studies in cities with traffic-related emissions have shown the importance of fine particulate matter, particularly $\mathrm{PM}_{2.5}$, in the development of certain acute and chronic health conditions (respiratory, including lung cancer, and cardiovascular, in particular) and daily mortality. A future challenge will be to determine whether this applies to volcanic PM, as the World Health Organization has concluded that these outcomes relate to geogenic as well as anthropogenic particulate exposures (World Health Organization 2013).

Currently we have little clinical evidence of whether chronic exposures to volcanic crystalline silica can trigger silicosis or lung cancer (World Health Organization 1997). Some toxicology studies have indicated biological mechanisms for silica-related diseases (Lee and Richards 2004; Damby et al. 2018b). However, there is also evidence that volcanic crystalline silica may not be particularly toxic (Damby et al. 2016). Geochemical and crystallographic studies indicate that, as with other forms of silica dusts (International Agency for Research on Cancer 1997; Donaldson and Borm 1998), there are inherent characteristics of the silica, and external factors, which may dampen its toxicity, such as chemical (e.g. aluminum) impurities in the crystal structure or the presence of the crystalline silica within an occluding complex mineral matrix (Horwell et al. 2012; Damby et al. 2014; Nattrass et al. 2017).

Conducting high-quality studies on health effects is challenging during an eruption crisis, and the need is often secondary to emergency response. Consequently, important opportunities to study population exposures and health impacts have been missed. Furthermore, many countries with frequent volcanism do not routinely gather public health statistics, or they may have low-quality population registers and no exposure monitoring in place. These conditions make health assessment and follow-up even more challenging. It is also extremely difficult to follow a cohort of people over decades, especially if exposures of study participants are curtailed due to evacuation or permanent migration following the eruption. Obtaining funding for longitudinal studies and having the long-term support of local healthcare professionals and facilities are also great challenges.

\section{Risk assessment and management}

Increased knowledge about the hazards posed by volcanic emissions now enables risk assessments (also known as Health Impact Assessments; HIA) to be conducted prior to, or during, eruptions. To date, three such assessments have been published: Hincks et al. (2006), on crystalline silicarich ash exposures on Montserrat; and Schmidt et al. (2011) and Heaviside et al. (2021) on $\mathrm{SO}_{2}$ /sulfate exposures from a future Laki-style eruption.

Mueller et al. (2020a) recently reviewed the potential for conducting HIAs in volcanic locations to predict future morbidity and mortality due to ash exposures from eruptions, given knowledge of eruption scenarios, baseline health data, and expected exposures. They concluded that, given the scarcity of published clinical/epidemiological studies and exposure data from eruptions, the application of outdoor urban air pollution risk estimates (concentration-response functions) to eruption scenarios was the best way to estimate the impact from volcanic ash exposures. Local climate, socioeconomic status, and quality of healthcare facilities also influence vulnerability and should be included in risk calculations.

Progress is being made in integrating atmospheric, volcanological, and medical information for real-time risk management. For example, detailed modeling of volcanic plume chemistry and transport from the 2014 to 2015 Holuhraun eruption informed exposure assessment (Carlsen et al. 2021a). At Kīlauea, characterizing vog $\left(\mathrm{SO}_{2}\right.$ and aerosol concentrations) has led to improved exposure assessments 
for studies seeking to understand vog health impacts (Tam et al. 2016).

Civil protection exercises for volcanic eruptions are now starting to include volcanic emissions (Holland et al. 2020; Witham et al. 2020). Such preparedness steps will help to identify where risks from volcanism need to be balanced against other local background issues and environmental hazards.

Due to the knowledge gaps, especially those related to the health effects of chronic exposures (e.g., to crystalline silica), a precautionary approach is generally taken to the management of health risks. Many agencies around the world will advise communities to reduce their exposures to volcanic air pollution. Little data exists on the efficacy of intervention strategies (air purifiers, dehumidifiers, or air conditioners) on indoor air quality in a volcanic environment. However, recent studies have provided an evidence base for the efficacy of wearing personal respiratory protection to reduce exposure to volcanic ash (Mueller et al. 2018; Steinle et al. 2018). The finding that industry-certified N95-style masks are most effective but hard to source and afford has led to some humanitarian organizations donating or crowdfunding such masks (Horwell et al. 2020). However, many government agencies distribute less-effective stockpiled masks, raising important ethical questions about the morality and legality of providing suboptimal protection (McDonald et al. 2020; McDonald and Horwell 2021). Provision of information on intervention effectiveness that is specific to local climates and cultures can help address such concerns. For example, IVHHN has produced informational products on protection from volcanic emissions, including on how to fit facemasks ${ }^{3}$. In Hawai'i, the advice has been tailored to local community lifestyles and published on a dedicated "vog dashboard" that is a single, freely accessible source of information, supported by multiple agencies. In multiple locations, ash, gas, and aerosol dispersion forecasts are linked to health information and advice for ongoing eruptions (Businger et al. 2015; Shiozawa et al. 2018; Barsotti et al. 2020). In Iceland, volcanic air pollution forecasts have been broadcast via radio and television and are available online (including social media) (Barsotti et al. 2020).

\section{Emerging themes, knowledge gaps, and future directions}

In general, few studies of health hazards and impacts are conducted relative to the number of eruptions that occur globally. Since 2001, the Global Volcanism Program ${ }^{5}$ has

\footnotetext{
${ }^{3}$ https://www.ivhhn.org/information\#printable

${ }^{4}$ https://www.vog.ivhhn.org
}

reported 124 eruptions of VEI $\geq 3$, while Table 2 reports 48 primary medical studies (at 23 volcanoes) assessing physical health effects of volcanic emissions. However, most of these studies were conducted in advanced-economy countries, notably the USA, Japan, and Iceland. Indonesia, with a 2021 population of $\sim 277$ million $^{6}$ and recent sustained and/or major eruptions of Merapi, Sinabung, Agung, and Semeru volcanoes, is notably under-represented, with a single clinical case study (Trisnawati et al. 2015). This inequality in attention, which relates to resources, opportunity, contacts, politics, and historical legacy, has meant that the health impacts of many major and sometimes longduration eruptions near large populations have gone completely unstudied. Additionally, with a few exceptions (e.g., Kīlauea, Holuhraun, and Miyakejima) where multiple studies of the health effects of exposure to $\mathrm{SO}_{2}$ and sulfate aerosol are reported (Table 2), effects of prolonged degassing have received little attention, relative to explosive eruptions, despite the chronic exposures and likely health effects.

A major research direction must be the development of methods for accurate exposure assessment. Further improvement of meteorological and dispersion models can help calculate ground-based pollutant concentrations at higher spatial and temporal resolution. Refining input parameters, plume models, and dynamic boundary layer representation, or incorporating advanced mathematical models such as Large Eddy Simulation, may also lead to much improved modeled concentrations (Barsotti et al. 2020; Burton et al. 2020, Holland et al. 2020; Filippi et al. 2021). Limitations in the accuracy and speciation of ground-level concentrations from models or space-based instruments will require the continuation of ground-based in situ measurements. Installation of networks of low-cost gas and particulate sensors is becoming increasingly feasible with a proliferation of technology in the past decade ${ }^{7}$. Such networks provide exciting opportunities for collaborative science with local communities. However, there are challenges for deployment during crises in terms of procurement and delivery in humanitarian situations where agencies have other priorities, and transport and other critical infrastructure networks may be disrupted. Currently, the utility of low-cost sensors is much greater when they are benchmarked against reference-grade instruments, which may not be available, even regionally. Future improvements in sensor accuracy, calibration, and reliable global satellite internet may contribute to better exposure assessment (Kizel et al. 2018; Crawford et al. 2021).

\footnotetext{
5 https://volcano.si.edu/

${ }^{6} \mathrm{https} / / / \mathrm{www}$. worldometers.info/world-population/indonesia-popul ation/

7 http://www.aqmd.gov/aq-spec
} 
We also foresee that air pollution research, in general, will move beyond a reliance on PM mass concentrations to assess impact and towards an understanding of the distinct PM chemical constituents, including metals and organic compounds, as well as towards physicochemical (e.g., surface area) or biological (e.g., oxidative potential) exposure metrics.

Interactions between volcanic eruptions and the ambient atmosphere and climate are an important future research direction with respect to health impacts. Ambient conditions influence the atmospheric dispersion and lifetime of volcanic emissions (for example, the sulfur gas-to-particle conversion rate; Gíslason et al. 2015), and ash remobilization in arid, windy climates may prolong population exposure (Jarvis et al. 2020). The consequences of global climate change for volcanic emission hazards are poorly understood but likely appreciable; for example, predicted weakening of Pacific trade winds will affect dispersion of emissions in Hawai' $i$ and Vanuatu (Collins et al. 2010).

The greatest overall barrier to advancing our understanding of volcanic air pollution effects on human health is the scarcity of epidemiological and clinical studies. To facilitate future studies, and support risk management, especially where local syndromic surveillance is absent, standardized epidemiological protocols (Mueller et al. 2020b) and crisis response resources ${ }^{8}$ have recently been developed. Instigating such studies will be facilitated by continued co-development of standardized protocols, supporting local study teams and procuring equipment, funding, and ethical permissions. Relationship building between visiting researchers and host country academic, observatory, and agency partners is vital for preserving host countries' intellectual property and ensuring beneficial research outcomes for impacted communities. In turn, this can support the effective communication of health impacts of volcanic air pollution to populations, health practitioners, and emergency managers.

Acknowledgements The authors sincerely thank Pierre-Yves Tournigand for graphic design of the manuscript figure. We also thank two anonymous reviewers and John Ewert of the U.S. Geological Survey for their review comments, which have improved this manuscript. Any use of trade, firm or product names is for descriptive purposes only and does not imply endorsement by the U.S. Government.

Author contribution CS formulated the initial proposal. CS and DED coordinated the content. CS, DED, CJH, and TE wrote parts of, and extensively revised, the manuscript. EI, IT, AS, HKC, EM, BML, PJB, and $\mathrm{CW}$ wrote part of the manuscript and/or assisted with the preparation of tables and figures (Table 1 IT; Table 2 BML). SC contributed to conceptual development and review. All authors read and approved the final manuscript.

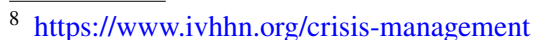

Funding CS acknowledges funding from New Zealand's Resilience to Nature's Challenges National Science Challenge. IT acknowledges the support received from the Agence Nationale de la Recherche of the French government through the program "Investissements d'Avenir" (16-IDEX-0001 CAP 20-25). AS acknowledges funding from Natural Environment Research Council grants NE/S00436X/1 and NE/ T006897/1.

\section{Declarations}

Conflict of interest The authors declare no competing interests.

Open Access This article is licensed under a Creative Commons Attribution 4.0 International License, which permits use, sharing, adaptation, distribution and reproduction in any medium or format, as long as you give appropriate credit to the original author(s) and the source, provide a link to the Creative Commons licence, and indicate if changes were made. The images or other third party material in this article are included in the article's Creative Commons licence, unless indicated otherwise in a credit line to the material. If material is not included in the article's Creative Commons licence and your intended use is not permitted by statutory regulation or exceeds the permitted use, you will need to obtain permission directly from the copyright holder. To view a copy of this licence, visit http://creativecommons.org/licenses/by/4.0/.

\section{References}

Allibone R, Cronin SJ, Charley DT, Neall VE, Stewart RB, Oppenheimer C (2012) Dental fluorosis linked to degassing of Ambrym volcano, Vanuatu: a novel exposure pathway. Environ Geochem Health 34:155-170. https://doi.org/10.1007/s10653-010-9338-2

Amaral AF, Rodrigues AS (2007) Chronic exposure to volcanic environments and chronic bronchitis incidence in the Azores, Portugal. Environ Res 103:419-423. https://doi.org/10.1016/j.envres. 2006.06.016

Armienta MA, De la Cruz-Reyna S, Morton O, Cruz O, Ceniceros N (2002) Chemical variations of tephra-fall deposit leachates for three eruptions from Popocatépetl volcano. Journal of Volcanology and Geothermal Research 113:61-80. https://doi.org/10. 1016/S0377-0273(01)00251-7

Armienta MA, Cruz-Reyna S, Cruz O, Ceniceros N, Aguayo A, Marin M (2011) Fluoride in ash leachates: environmental implications at Popocatépetl volcano, central Mexico. Natural Hazards and Earth System Sciences 11:1949-1956. https://doi.org/10.5194/ nhess-11-1949-2011

Atanga MBS, Van der Meerve AS, Shemamg EM, Suh CE, Kruger W, Njome MS, Asobo NE (2009) Volcanic Ash from the 1999 Eruption of Mount Cameroon volcano: characterization and implications to health hazards. Afr J Online 8:63-70. https://www.ajol. info/index.php/jcas/article/view/87049

Balsa AI, Caffera M, Bloomfield J (2016) Exposures to particulate matter from the eruptions of the Puyehue Volcano and birth outcomes in Montevideo, Uruguay. Environ Health Perspect 124:1816-1822. https://doi.org/10.1289/EHP235

Barone G, De Giudici G, Gimeno D, Lanzafame G, Podda F, Cannas C, Giuffrida A, Barchitta M, Agodi A, Mazzoleni P (2021) Surface reactivity of Etna volcanic ash and evaluation of health risks. Science of the Total Environment 761:143248. https://doi.org/ 10.1016/j.scitotenv.2020.143248

Barsotti S (2020) Probabilistic hazard maps for operational use: the case of $\mathrm{SO}_{2}$ air pollution during the Holuhraun eruption (Bárðarbunga, Iceland) in 2014-2015. Bull Volcanol 82:56. https://doi. org/10.1007/s00445-020-01395-3 
Barsotti S, Oddsson B, Gudmundsson MT, Pfeffer MA, Parks MM, Ófeigsson BG, Sigmundsson F, Reynisson V, Jónsdóttir K, Roberts MJ, Heiðarsson EP, Jónasdóttir EB, Einarsson P, Jóhannsson T, Gylfason ÁG, Vogfjörd K (2020) Operational response and hazards assessment during the 2014-2015 volcanic crisis at Bárðarbunga volcano and associated eruption at Holuhraun, Iceland. J Volcanol Geotherm Res 390:106753. https://doi.org/ 10.1016/j.jvolgeores.2019.106753

Bates MN, Garrett N, Crane J, Balmes JR (2013) Associations of ambient hydrogen sulfide exposure with self-reported asthma and asthma symptoms. Environ Res 122:81-87. https://doi.org/10. 1016/j.envres.2013.02.002

Bates MN, Crane J, Balmes JR, Garrett N (2015) Investigation of hydrogen sulfide exposure and lung function, asthma and chronic obstructive pulmonary disease in a geothermal area of New Zealand. PLoS One 10:e0122062. https://doi.org/10.1371/journal. pone. 0122062

Baxter PJ, Bonadonna C, Dupree R, Hards VL, Kohn SC, Murphy MD, Nichols A, Nicholson RA, Norton G, Searl A, Sparks RS, Vickers BP (1999) Cristobalite in volcanic ash of the Soufrière Hills volcano, Montserrat, British West Indies. Science 283:11421145. https://doi.org/10.1126/science.283.5405.1142

Baxter PJ, Searl AS, Cowie HA, Jarvis D, Horwell CJ (2014) Evaluating the respiratory health risks of volcanic ash at the eruption of the Soufrière Hills volcano, Montserrat, 1995-2010. Geological Society of London Memoirs 39:407-425. https://doi.org/10. 1144/M39.22

BéruBé KA, Jones TP, Housley DG, Richards RJ (2004) The respiratory toxicity of airborne volcanic ash from the Soufrière Hills volcano, Montserrat. Mineralogical Magazine 68:47-60. https:// doi.org/10.1180/0026461046810170

Bia G, Borgnino L, Zampieri G, Garcia MG (2020) Fluorine surface speciation in South Andean volcanic ashes. Chemical Geology 532:119402. https://doi.org/10.1016/j.chemgeo.2019.119402

Bosshard-Stadlin SA, Mattsson HB, Stewart C, Reusser E (2017) Leaching of lava and tephra from the Oldoinyo Lengai volcano (Tanzania): remobilization of fluorine and other potentially toxic elements into surface waters of the Gregory Rift. Journal of Volcanology and Geothermal Research 332:14-25. https://doi.org/ 10.1016/j.jvolgeores.2017.01.009

Brown SK, Jenkins SF, Sparks RSJ, Odbert H, Auker MR (2017) Volcanic fatalities database: analysis of volcanic threat with distance and victim classification. J Appl Volcanol 6:15. https://doi.org/ 10.1186/s13617-017-0067-4

Budianta W (2011) The potential impact of ash Merapi Volcano eruption 2010 in Yogyakarta, Indonesia, for the environment and human health. Journal of Applied Geology 3:111-115. https:// doi.org/10.22146/jag. 7187

Burton RR, Woodhouse MJ, Gadian AM, Mobbs SD (2020) The use of a numerical weather prediction model to simulate near-field volcanic plumes. Atmosphere 11:594. https://doi.org/10.3390/ atmos11060594

Businger S, Huff R, Horton K, Sutton AJ, Elias T (2015) Observing and forecasting vog dispersion from Kīlauea Volcano, Hawai'i. Bull Amer Meteor Soc 96:1667-1686. https://doi.org/10.1175/ BAMS-D-14-00150.1

Cadelis G, Tourres R, Molinie J, Petit RH (2013) Exacerbations of asthma in Guadeloupe (French West Indies) and volcanic eruption in Montserrat (70 km from Guadeloupe). Rev Mal Respir 30:203-214. https://doi.org/10.1016/j.rmr.2012.11.002

Camara JG, Lagunzad JK (2011) Ocular findings in volcanic fog induced conjunctivitis. Hawai'i Med J 70:262-265

Cangemi M, Speziale S, Madonia P, D'Alessandro W, Andronico D, Bellomo S, Brusca L, Kyriakopoulos K (2017) Potentially harmful elements released by volcanic ashes: examples from the Mediterranean area. Journal of Volcanology and Geothermal Research 337:16-28. https://doi.org/10.1016/j.jvolgeores. 2017.03.015

Carlsen HK, Gíslason T, Benediktsdóttir B, Kolbeinsson TB, Hauksdóttir A, Thorsteinsson T, Briem H (2012a) A survey of early health effects of the Eyjafjallajökull 2010 eruption in Iceland: a population-based study. BMJ Open 2:e000343. https://doi.org/ 10.1136/bmjopen-2011-000343

Carlsen HK, Hauksdóttir A, Valdimarsdóttir UA, Gíslason T, Einarsdóttir G, Runolfsson H, Briem H, Finnbjornsdóttir RG, Gudmundsson S, Kolbeinsson TB, Thorsteinsson T, Pétursdóttir G (2012b) Health effects following the Eyjafjallajökull volcanic eruption: a cohort study. BMJ Open 2:e001851. https://doi.org/ 10.1136/bmjopen-2012-001851

Carlsen HK, Aspelund T, Briem H, Gíslason T, Jóhannsson T, Valdimarsdóttir U, Gudnason T (2019) Respiratory health among professionals exposed to extreme $\mathrm{SO}_{2}$ levels from a volcanic eruption. Scand J Work Environ Health 45:312-315. https://doi. org/10.5271/sjweh.3783

Carlsen HK, Ilyinskaya E, Baxter PJ, Schmidt A, Thorsteinsson T, Pfeffer MA, Barsotti S, Dominici F, Finnbjornsdóttir RG, Jóhannsson T, Aspelund T, Gíslason T, Valdimarsdóttir U, Briem H, Gudnason T (2021a) Increased respiratory morbidity associated with exposure to a mature volcanic plume from a large Icelandic fissure eruption. Nat Commun 12:2161. https://doi.org/10.1038/ s41467-021-22432-5

Carlsen HK, Valdimarsdóttir U, Briem H et al (2021b) Severe volcanic $\mathrm{SO}_{2}$ exposure and respiratory morbidity in the Icelandic population - a register study. Environ Health 20:23. https://doi.org/10. 1186/s12940-021-00698-y

Chow DC, Grandinetti A, Fernandez E, Sutton AJ, Elias T, Brooks B, Tam EK (2010) Is volcanic air pollution associated with decreased heart-rate variability? Heart Asia 2:36-41. https:// doi.org/10.1136/ha.2009.001172

Collins M, An SI, Cai W et al (2010) The impact of global warming on the tropical Pacific Ocean and El Niño. Nature Geosci 3:391-397. https://doi.org/10.1038/ngeo868

Connell J, Lutkehaus N (2017) Escaping Zaria's fire? The volcano resettlement problem of Manam Island, Papua New Guinea. Asia Pacific Viewpoint 58:14. https://doi.org/10.1111/apv.12148

Crawford B, Hagan DH, Grossman I, Cole E, Holland L, Heald CL, Kroll JH (2021) Mapping pollution exposure and chemistry during an extreme air quality event (the 2018 Kilauea eruption) using a low-cost sensor network. PNAS 118:27. https://doi.org/ 10.1073/pnas.2025540118

Cronin SJ, Sharp DS (2002) Environmental impacts on health from continuous volcanic activity at Yasur (Tanna) and Ambrym, Vanuatu. International Journal of Environmental Health Research 12:109-123. https://doi.org/10.1080/09603120220129274

Cronin SJ, Stewart C, Zernack AV, Brenna M, Procter JN, Pardo N, Christenson B, Wilson T, Stewart RB, Irwin M (2014) Volcanic ash leachate compositions and assessment of health and agricultural hazards from 2012 hydrothermal eruptions, Tongariro, New Zealand. Journal of Volcanology and Geothermal Research 286:233-247. https://doi.org/10.1016/j.jvolgeores.2014.07.002

Cullen RT, Jones AD, Miller BG, Tran CL, Davis JM, Donaldson K, Wilson M, Stone V, Morgan A (2002) Toxicity of volcanic ash from Montserrat. Institute of Occupational Medicine Research Report TM/02/01 April 2002. https://citeseerx.ist.psu.edu/viewd oc/download?doi=10.1.1.599.9295\&rep=rep1\&type $=$ pdf

Cuthbertson J, Stewart C, Lyon A, Burns P, Telopo T (2020) Health impacts of volcanic activity in Oceania. Prehospital and Disaster Medicine 35:574-578. https://doi.org/10.1017/S1049023X2 000093X 
D'Alessandro W (2006) Human fluorosis related to volcanic activity: a review. In: WIT Transactions on Biomedicine and Health 10:21-30. https://doi.org/10.2495/ETOX060031

Daga R, Guevara SR, Poire DG, Arribére M (2014) Characterization of tephras dispersed by the recent eruptions of volcanoes Calbuco (1961), Chaitén (2008) and Cordón Caulle Complex (1960 and 2011), in Northern Patagonia. Journal of South American Earth Sciences 49:1-4. https://doi.org/10.1016/j.jsames.2013.10.006

Damby DE (2012) From dome to disease: The respiratory toxicity of volcanic cristobalite. Dissertation, Durham University. http:// etheses.dur.ac.uk/7328/1/damby_thesis.pdf

Damby DE, Horwell CJ, Baxter PJ, Delmelle P, Donaldson K, Dunster C, Fubini B, Murphy FA, Nattrass C, Sweeney S, Tetley TD (2013) The respiratory health hazard of tephra from the 2010 Centennial eruption of Merapi with implications for occupational mining of deposits. Journal of Volcanology and Geothermal Research 261:376-387. https://doi.org/10.1016/j.jvolgeores. 2012.09.001

Damby DE, Llewellin EW, Horwell CJ, Williamson BJ et al (2014) The alpha-beta phase transition in volcanic cristobalite. J Appl Crystallogr 47:4. https://doi.org/10.1107/S160057671401070X

Damby DE, Murphy FA, Horwell CJ, Raftis J, Donaldson K (2016) The in vitro respiratory toxicity of cristobalite-bearing volcanic ash. Environ Res 145:74-84. https://doi.org/10.1016/j.envres. 2015.11.020

Damby DE, Horwell CJ, Larsen G, Thordarson T, Tomatis M, Fubini B, Donaldson K (2017) Assessment of the potential respiratory hazard of volcanic ash from future Icelandic eruptions: a study of archived basaltic to rhyolitic ash samples. Environ Health 16:98. https://doi.org/10.1186/s12940-017-0302-9

Damby DE, Peek S, Lerner AH, Elias T (2018a) Volcanic ash leachate chemistry from increased 2018 activity of Kīlauea volcano. U.S. Geological Survey data release, Hawai'i. https://doi.org/10.5066/ P98A07DC. https://www.sciencebase.gov/catalog/item/5b69c be6e4b006a11f775784

Damby DE, Horwell CJ, Baxter PJ, Kueppers U et al (2018b) Volcanic ash activates the NLRP3 inflammasome in murine and human macrophages. Front Immunol 8:2000. https://doi.org/10.3389/ fimmu. 2017.02000

de Lima EF, Sommer CA, Cordeiro Silva IM, Netta AP, Lindenberg M, Marques Alves R (2012) Morphology and chemistry of the Puyehue volcano ashes deposited at Porto Alegre metropolitan region in June 2011. Revista Brasiliera de Geociências 42:265280. https://doi.org/10.5327/Z0375-75362012000200004

Delmelle P (2003) Environmental impacts of tropospheric volcanic gas plumes. Geol Soc Lond Spec Publ 213:381-399. https://doi.org/ 10.1144/GSL.SP.2003.213.01.23

Donaldson K, Borm PJA (1998) The quartz hazard: a variable entity. The Annals of Occupational Hygiene 42:287-294. https://doi. org/10.1093/annhyg/42.5.287

Doocy S, Daniels A, Dooling S, Gorokhovich Y (2013) The human impact of volcanoes: a historical review of events 1900-2009 and systematic literature review. PLoS Curr 16:5. https://doi.org/10. 1371/currents.dis.841859091a706efebf8a30f4ed7a1901

Durand M, Wilson JG (2006) Spatial analysis of respiratory disease on an urbanized geothermal field. Environ Res 101:238-245. https:// doi.org/10.1016/j.envres.2005.08.006

Durant AJ, Villarosa G, Rose WI, Delmelle P, Prata AJ, Viramonte JG (2012) Long-range volcanic ash transport and fallout during the 2008 eruption of Chaitén volcano, Chile. Physics and Chemistry of the Earth Parts A/B/C 45-46:50-64. https://doi.org/10.1016/j. pce.2011.09.004

Elliot AJ, Singh N, Loveridge P, Harcourt S, Smith S, Pnaiser R, Kavanagh K, Robertson C, Ramsay CN, McMenamin J, Kibble A, Murray V, Ibbotson S, Catchpole M, McCloskey B, Smith GE (2010) Syndromic surveillance to assess the potential public health impact of the Icelandic volcanic ash plume across the United Kingdom, April 2010. Euro Surveill 15:19583

Eychenne J, Cashman K, Rust A, Durant A (2015) Impact of the lateral blast on the spatial pattern and grain size characteristics of the 18 May 1980 Mount St. Helens fallout deposit. J Geophys Res Solid Earth 120:6018-6038. https://doi.org/10.1002/2015JB012116

Fano V, Cernigliaro A, Scondotto S, Perucci CA, Forastiere F (2010) The fear of volcano: short-term health effects after Mount Etna's eruption in 2002. Eur Respir J 36:1216-1218. https://doi.org/10. 1183/09031936.00078910

Felton D, Grange G, Damby DE, Bronstein A, Spyker D (2019) Sulfur dioxide monitoring associated with the 2018 Kilauea Lower East Rift Zone Eruption. International Union of Toxicology (IUTOX) 15th International Congress of Toxicology, Honolulu, HI, USA

Filippi J-B, Durand J, Tulet P, Bielli S (2021) Multiscale modeling of convection and pollutant transport associated with volcanic eruption and lava flow: application to the April 2007 eruption of the Piton de la Fournaise (Réunion Island). Atmosphere 12:507. https://doi.org/10.3390/atmos12040507

Forbes L, Jarvis D, Potts J, Baxter PJ (2003) Volcanic ash and respiratory symptoms in children on the island of Montserrat, British West Indies. Occup Environ Med 60:207-211. https://doi.org/ 10.1136/oem.60.3.207

Freire S, Florczyk AJ, Pesaresi M, Sliuzas R (2019) An improved global analysis of population distribution in proximity to active volcanoes, 1975-2015. ISPRS International Journal of GeoInformation 8:341. https://doi.org/10.3390/ijgi8080341

Gíslason SR, Stefánsdóttir G, Pfeffer MA, Barsotti S, Jóhannsson Th, Galeczka I, Bali E, Sigmarsson O, Stefánsson A, Keller NS, Sigurdsson Á, Bergsson B, Galle B, Jacobo VC, Arellano S, Aiuppa A, Jónasdóttir EB, Eiríksdóttir ES, Jakobsson S, Guðfinnsson GH, Halldórsson SA, Gunnarsson H, Haddadi B, Jónsdóttir I, Thordarson Th, Riishuus M, Högnadóttir Th, Dürig T, Pedersen GBM, Höskuldsson Á, Gudmundsson MT (2015) Environmental pressure from the 2014-15 eruption of Bárðarbunga volcano, Iceland. Geochemical Perspectives Letters 1:84-93. https://doi. org/10.7185/geochemlet.1509

Greenberg MI, Waksman J, Curtis J (2007) Silicosis: a review. Diseasea-Month 53:394-416. https://doi.org/10.1016/j.disamonth.2007. 09.020

Gudmundsson G (2011) Respiratory health effects of volcanic ash with special reference to Iceland: a review. Clin Respir J 5:2-9. https:// doi.org/10.1111/j.1752-699X.2010.00231.x

Hansell A, Oppenheimer C (2004) Health hazards from volcanic gases: a systematic literature review. Arch Environ Health 59:628-639. https://doi.org/10.1080/00039890409602947

Heaviside C, Witham C, Vardoulakis S (2021) Potential health impacts from sulfur dioxide and sulfate exposure in the UK resulting from an Icelandic effusive eruption. Science of the Total Environment 774:145549. https://doi.org/10.1016/j.scitotenv.2021.145549

Heggie TW (2005) Reported fatal and non-fatal incidents involving tourists in Hawai'i Volcanoes National Park, 1992-2002. Travel Med Infect Dis 3:123-131. https://doi.org/10.1016/j.tmaid.2004. 09.004

Heggie TW, Heggie TM, Heggie TJ (2009) Death by volcanic laze. Wilderness Environ Med 20:101-103. https://doi.org/10.1580/ 08-WEME-LE-236.1

Higuchi K, Koriyama C, Akiba S (2012) Increased mortality of respiratory diseases, including lung cancer, in the area with large amount of ashfall from Mount Sakurajima volcano. J Environ Public Health 2012:257831. https://doi.org/10.1155/2012/ 257831

Hillman SE, Horwell CJ, Densmore AL, Damby DE, Fubini B, Ishimine Y, Tomatis M (2012) Sakurajima volcano: a physicochemical study of the health consequences of long-term exposure 
to volcanic ash. Bulletin of Volcanology 74:913-930. https://doi. org/10.1007/s00445-012-0575-3

Hincks TK, Aspinall WP, Baxter PJ, Searl A, Sparks RSJ, Woo G (2006) Long-term exposure to respirable volcanic ash on Montserrat: a time-series simulation. Bull Volcanol 68:264-266. https://doi.org/10.1007/s00445-005-0006-9

Hlodversdóttir H, Petursdóttir G, Carlsen HK, Gíslason T, Hauksdóttir A (2016) Long-term health effects of the Eyjafjallajökull volcanic eruption: a prospective cohort study in 2010 and 2013. BMJ Open 6(9):e011444. https://doi.org/10.1136/bmjop en-2016-011444

Hlodversdóttir H, Thorsteinsdóttir H, Thordardóttir EB, Njardvik U, Petursdóttir G, Hauksdóttir A (2018) Long-term health of children following the Eyjafjallajökull volcanic eruption: a prospective cohort study. Eur J Psychotraumatol 9:1442601. https://doi. org/10.1080/20008198.2018.1442601

Holland L, Businger S, Elias T, Cherubini T (2020) Two ensemble approaches for forecasting sulfur dioxide concentrations from Kīlauea Volcano. Wea Forecasting 35:1923-1937. https://doi. org/10.1175/WAF-D-19-0189.1

Horwell CJ (2007) Grain-size analysis of volcanic ash for the rapid assessment of respiratory health hazard. Journal of Environmental Monitoring 9:1107-1115. https://doi.org/10.1039/B710583P

Horwell CJ, Baxter PJ (2006) The respiratory health hazards of volcanic ash: a review for volcanic risk mitigation. Bulletin of Volcanology 69:1-24. https://doi.org/10.1007/s00445-006-0052-y

Horwell CJ, Sparks RSJ, Brewer TS, Llewellin EW, Williamson BJ (2003a) Characterization of respirable volcanic ash from the Soufrière Hills volcano, Montserrat, with implications for human health hazards. Bulletin of Volcanology 65:346-362. https://doi. org/10.1007/s00445-002-0266-6

Horwell CJ, Fenoglio I, Ragnarsdóttir KV, Sparks RSJ, Fubini B (2003b) Surface reactivity of volcanic ash from the eruption of Soufrière Hills volcano, Montserrat, West Indies with implications for health hazards. Environmental Research 93:202-215. https://doi.org/10.1016/S0013-9351(03)00044-6

Horwell CJ, Fenoglio I, Fubini B (2007) Iron-induced hydroxyl radical generation from basaltic volcanic ash. Earth Planet Sci Lett 261:662-669. https://doi.org/10.1016/j.epsl.2007.07.032

Horwell CJ, Le Blond JS, Michnowicz SA, Cressey G (2010a) Cristobalite in a rhyolitic lava dome: evolution of ash hazard. Bulletin of Volcanology 72:249-253. https://doi.org/10.1007/ s00445-009-0327-1

Horwell CJ, Stannett GW, Andronico D, Bertagnini A, Fenoglio I, Fubini B, Le Blond JS, Williamson BJ (2010b) A physico-chemical assessment of the health hazard of Mt. Vesuvius volcanic ash. J Volcanol Geotherm Res 191:222-232. https://doi.org/10. 1016/j.jvolgeores.2010.01.014

Horwell C, Williamson B, Donaldson K, Le Blond J, Damby D, Bowen L (2012) The structure of volcanic cristobalite in relation to its toxicity; relevance for the variable crystalline silica hazard. Part Fibre Toxicol 9:44. https://doi.org/10.1186/1743-8977-9-44

Horwell CJ, Baxter PJ, Hillman SE, Calkins JA, Damby DE, Delmelle P, Donaldson K, Dunster C, Fubini B, Kelly FJ, Le Blond JS (2013) Physicochemical and toxicological profiling of ash from the 2010 and 2011 eruptions of Eyjafjallajökull and Grímsvötn volcanoes, Iceland using a rapid respiratory hazard assessment protocol. Environmental Research 127:63-73. https://doi.org/10. 1016/j.envres.2013.08.011

Horwell CJ, Hillman SE, Cole, PD, Loughlin SC, Llewellin EW, Damby DE, Christopher TE (2014) Controls on variations in cristobalite abundance in ash generated by the Soufrière Hills Volcano, Montserrat in the period 1997 to 2010. In: Wadge G, Robertson REA and Voight B (eds.) The eruption of Soufrière Hills Volcano, Montserrat from 2000 to 2010. Geological Society of London 399-406. (Memoir 39). https://doi.org/10.1144/M39. 21

Horwell CJ, Sargent P, Andronico D, Castro ML, Tomatis M, Hillman SE, Michnowicz SA, Fubini B (2017) The iron-catalysed surface reactivity and health-pertinent physical characteristics of explosive volcanic ash from Mt. Etna. Italy. Journal of Applied Volcanology 6:1-6. https://doi.org/10.1186/s13617-017-0063-8

Horwell CJ, Covey J, Merli C, Dominelli et al (2020) Preparing for, and protecting communities from, respiratory exposure to volcanic ash. PAHO/WHO Emergencies Disasters Newsletter, Supplement on Health Disaster Risk Reduction. October 2020, Issue 130. https://www3.paho.org/disasters/newsletter/index.php? option=com_content $\&$ view $=$ category $\&$ id $=320 \&$ Itemid $=101 \&$ lang=en

Ilyinskaya E, Schmidt A, Mather TA, Pope FD, Witham C, Baxter P, Jóhannsson T, Pfeffer M, Barsotti S, Singh A, Sanderson P, Bergsson B, Kilbride BM, Donovan A, Peters N, Oppenheimer C, Edmonds M (2017) Understanding the environmental impacts of large fissure eruptions: aerosol and gas emissions from the 2014-2015 Holuhraun eruption (Iceland). Earth Planet Sci Lett 472:309-322. https://doi.org/10.1016/j.eps1.2017.05.025

Ilyinskaya E, Mason E, Wieser PE et al (2021) Rapid metal pollutant deposition from the volcanic plume of Kīlauea, Hawai'i. Commun Earth Environ 2:78. https://doi.org/10.1038/ s43247-021-00146-2

International Agency for Research on Cancer (1997) Silica, some silicates, coal dust and para-aramid fibrils. IARC Monographs on the Evaluation of Carcinogenic Risks to Humans 68

Ishigami A, Kikuchi Y, Iwasawa S, Nishiwaki Y, Takebayashi T, Tanaka S, Omae K (2008) Volcanic sulfur dioxide and acute respiratory symptoms on Miyakejima island. Occup Environ Med 65:701-707. https://doi.org/10.1136/oem.2007.033456

Iwasawa S, Kikuchi Y, Nishiwaki Y, Nakano M, Michikawa T, Tsuboi T, Tanaka S, Uemura T, Ishigami A, Nakashima H, Takebayashi T, Adachi M, Morikawa A, Maruyama K, Kudo S, Uchiyama I, Omae K (2009) Effects of $\mathrm{SO}_{2}$ on respiratory system of adult Miyakejima residents 2 years after returning to the island. J Occup Health 51:38-47. https://doi.org/10.1539/joh.18075

Iwasawa S, Nakano M, Tsuboi T, Kochi T, Tanaka S, Katsunuma T, Morikawa A, Omae K (2015) Effects of sulfur dioxide on the respiratory system of Miyakejima child residents 6 years after returning to the island. Int Arch Occup Environ Health 88:11111118. https://doi.org/10.1007/s00420-015-1037-y

Jarvis P, Bonadonna C, Dominguez L et al (2020) Aeolian remobilisation of volcanic ash: outcomes of a workshop in the Argentinian Patagonia. Frontiers in Earth Sciences 8. https://doi.org/10.3389/ feart.2020.575184

Jenkins SF, Wilson T, Magill C, Miller V, Stewart C, Blong R, Marzocchi W, Boulton M, Bonadonna C, Costa A (2015) Volcanic ash fall hazard and risk. In: Loughlin SC, Sparks RSJ, Brown SK, Jenkins SF, Vye-Brown C (eds) Global Volcanic Hazards and Risk. Cambridge University Press, Cambridge. https://doi.org/ 10.1017/CBO9781316276273.005

Jones T, BéruBé K (2011) The bioreactivity of the sub-10 $\mu \mathrm{m}$ component of volcanic ash: Soufrière Hills volcano, Montserrat. Journal of Hazardous Materials 194:128-134. https://doi.org/10.1016/j. jhazmat.2011.07.092

Kelly FJ (2003) Oxidative stress: its role in air pollution and adverse health effects. Occup Environ Med 60:612-616. https://doi.org/ 10.1136/oem.60.8.612

Kimura K, Sakamoto T, Miyazaki M, Uchino E, Kinukawa N, Isashiki M (2005) Effects of volcanic ash on ocular symptoms: results of a 10-year survey on schoolchildren. Ophthalmology 112:478481. https://doi.org/10.1016/j.ophtha.2004.09.031

Kizel F, Etzion Y, Shafran-Nathan R, Levy I, Fishbain B, Bartonova A, Broday DM (2018) Node-to-node field calibration of wireless 
distributed air pollution sensor network. Environmental Pollution 233:900-909. https://doi.org/10.1016/j.envpol.2017.09.042

Kochi T, Iwasawa S, Nakano M, Tsuboi T, Tanaka S, Kitamura H, Wilson DJ, Takebayashi T, Omae K (2017) Influence of sulfur dioxide on the respiratory system of Miyakejima adult residents 6 years after returning to the island. J Occup Health 59:313-326. https://doi.org/10.1539/joh.16-0256-OA

Le Blond JS, Cressey G, Horwell CJ, Williamson BJ (2009) A rapid method for quantifying single mineral phases in heterogeneous natural dusts using X-ray diffraction. Powder Diffract 24:17-23. https://doi.org/10.1154/1.3077941

Le Blond JS, Horwell CJ, Baxter PJ, Michnowicz SA, Tomatis M, Fubini B, Delmelle P, Dunster C, Patia H (2010) Mineralogical analyses and in vitro screening tests for the rapid evaluation of the health hazard of volcanic ash at Rabaul volcano, Papua New Guinea. Bulletin of Volcanology 72:1077-1092. https://doi.org/ 10.1007/s00445-010-0382-7

Lee SH, Richards RJ (2004) Montserrat volcanic ash induces lymph node granuloma and delayed lung inflammation. Toxicology 195:155-165. https://doi.org/10.1154/1.3077941

Linhares D, Ventura Garcia P, Viveiros F, Ferreira T, dos Santos RA (2015) Air pollution by hydrothermal volcanism and human pulmonary function. Biomed Res Int 2015:326794. https://doi.org/ $10.1155 / 2015 / 326794$

Lombardo D, Ciancio N, Campisi R, Di Maria A, Bivona L, Poletti V, Mistretta A, Biggeri A, Di Maria G (2013) A retrospective study on acute health effects due to volcanic ash exposure during the eruption of Mount Etna (Sicily) in 2002. Multidiscip Respir Med 8:51. https://doi.org/10.1186/2049-6958-8-51

Longo BM (2009) The Kilauea Volcano adult health study. Nurs Res 58:23-31. https://doi.org/10.1097/NNR.0b013e3181900cc5

Longo BM (2013) Adverse health effects associated with increased activity at Kīlauea Volcano: a repeated population-based survey. ISRN Public Health 1-10. https://doi.org/10.1155/2013/475962

Longo BM, Yang W (2008) Acute bronchitis and volcanic air pollution: a community-based cohort study at Kilauea Volcano, Hawai'i, USA. J Toxicol Environ Health A 71:1565-1571. https://doi.org/ $10.1080 / 15287390802414117$

Longo BM, Rossignol A, Green JB (2008) Cardiorespiratory health effects associated with sulphurous volcanic air pollution. Public Health 122:809-820. https://doi.org/10.1016/j.puhe.2007.09.017

Longo BM, Yang W, Green JB, Crosby FL, Crosby VL (2010) Acute health effects associated with exposure to volcanic air pollution (vog) from increased activity at Kilauea Volcano in 2008. J Toxicol Environ Health A 73:1370-1381. https://doi.org/10.1080/ 15287394.2010.497440

Macomber P (2020) Guidelines on rainwater catchment systems for Hawai'i. College of Tropical Agriculture and Human Resources, University of Hawai'i. https://www.ctahr.hawaii.edu/hawaiirain/ Library/Guides\&Manuals/HI_Guidelines_2020.pdf

Mason E, Wieser PE, Liu EJ, Edmonds M, Ilyinskaya E, Whitty RCW, Mather TA, Elias T, Nadeau PA, Wilkes TC, McGonigle AJS, Pering TD, Mims FM, Kern C, Schneider D, Oppenhemier C (2021) Volatile metal emissions from volcanic degassing and lava-seawater interactions at Kîlauea Volcano. Hawai'i. Commun Earth Environ 2:79. https://doi.org/10.1038/s43247-021-00145-3

Mather TA, Allen AG, Oppenheimer C et al (2003) Size-resolved characterisation of soluble ions in the particles in the tropospheric plume of Masaya Volcano, Nicaragua: Origins and Plume Processing. J Atmos Chem 46:207-237. https://doi.org/10.1023/A: 1026327502060

McDonald F, Horwell CJ (2021) Air pollution disasters: Liability issues in negligence associated with the provision of personal protective interventions (facemasks). Disaster Medicine and Public Health Preparedness 15:367-373. https://doi.org/10.1017/dmp.2020.37
McDonald F, Horwell CJ, Wecker R, Dominelli L, Loh M, Kamanyire R, Ugarte C (2020) Facemask use for community protection from air pollution disasters: an ethical overview and framework to guide agency decision making. International Journal of Disaster Risk Reduction 43:101376. https://doi.org/10.1016/j.ijdrr.2019. 101376

Michaud JP, Grove JS, Krupitsky D (2004) Emergency department visits and "vog"-related air quality in Hilo, Hawai'i. Environ Res 95:11-19. https://doi.org/10.1016/S0013-9351(03)00122-1

Michellier C, Katoto PMC, Dramaix M, Nemery B, Kervyn F (2020) Respiratory health and eruptions of the Nyiragongo and Nyamulagira volcanoes in the Democratic Republic of Congo: a timeseries analysis. Environ Health 9:62. https://doi.org/10.1186/ s12940-020-00615-9

Monick MM, Baltrusaitis J, Powers LS, Borcherding JA, Caraballo JC, Mudunkotuwa I, Peate DW, Walters K, Thompson JM, Grassian VH, Gudmundsson G (2013) Effects of Eyjafjallajökull volcanic ash on innate immune system responses and bacterial growth in vitro. Environmental Health Perspectives 121:691-698. https://doi.org/10.1289/ehp.1206004

Mueller W, Horwell CJ, Apsley A, Steinle S, McPherson S, Cherrie JW, Galea KS (2018) The effectiveness of respiratory protection worn by communities to protect from volcanic ash inhalation. Part I: Filtration efficiency tests. Int J Hyg Environ Health 221:967-976. https://doi.org/10.1016/j.ijheh.2018.03.012

Mueller W, Cowie H, Horwell CJ, Hurley F, Baxter P (2020a) Health impact assessment of volcanic ash inhalation: a comparison with outdoor air pollution methods. GeoHealth 4:e2020GH000256. https://doi.org/10.1029/2020GH000256

Mueller W, Cowie H, Horwell CJ, Baxter PJ, McElvenny D, Booth M, Cherrie JW, Cullinan P, Jarvis D, Ugarte C, Inoue H (2020b) Standardised epidemiological protocols for populations affected by volcanic eruptions. Bull World Health Organ 98:362-364. https://doi.org/10.2471/BLT.19.244509

Nattrass C, Horwell CJ, Damby DE, Brown D, Stone V (2017) The effect of aluminium and sodium impurities on the in vitro toxicity and pro-inflammatory potential of cristobalite. Environ Res 159:164-175. https://doi.org/10.1016/j.envres.2017.07. 054

Naumova EN, Yepes H, Griffiths JK, Sempértegui F, Khurana G, Jagai JS, Játiva E, Estrella B (2007) Emergency room visits for respiratory conditions in children increased after Guagua Pichincha volcanic eruptions in April 2000 in Quito, Ecuador observational study: time series analysis. Environ Health 6:21. https://doi.org/10.1186/1476-069X-6-21

Newnham RM, Dirks KN, Samaranayake D (2010) An investigation into long-distance health impacts of the 1996 eruption of Mt Ruapehu, New Zealand. Atmospheric Environment 44:15681578. https://doi.org/10.1016/j.atmosenv.2009.12.040

Nieto-Torres A, Martin-Del Pozzo AL (2021) Ash emission from a long-lived eruption at Popocatépetl volcano and mapped respiratory effects. Bulletin of Volcanology 83:68. https://doi.org/ 10.1007/s00445-021-01490-z

Olsson J, Stipp SL, Dalby KN, Gíslason SR (2013) Rapid release of metal salts and nutrients from the 2011 Grímsvötn, Iceland volcanic ash. Geochimica et Cosmochimica Acta 123:134-149. https://doi.org/10.1016/j.gca.2013.09.009

Oppenheimer C, Pyle DM, Barclay J (2003) Volcanic Degassing. Geological Society of London, Special Publications 213. https://doi.org/10.1144/GSL.SP.2003.213

Oudin A, Carlsen HK, Forsberg B, Johansson C (2013) Volcanic ash and daily mortality in Sweden after the Icelandic volcano eruption of May 2011. Int J Environ Res Public Health 10:69096919. https://doi.org/10.3390/ijerph10126909

Paez PA, Cogliati MG, Caselli AT, Monasterio AM (2021) An analysis of volcanic $\mathrm{SO}_{2}$ and ash emissions from Copahue volcano. 
Journal of South American Earth Sciences 103365. https://doi. org/10.1016/j.jsames.2021.103365

Prüss-Ustün A, Vickers C, Haefliger P, Bertollini R (2011) Knowns and unknowns on burden of disease due to chemicals: a systematic review. Environ Health 10:9. https://doi.org/10.1186/ 1476-069X-10-9

Reich M, Zúñiga A, Amigo A, Vargas G, Morata D, Palacios C, Parada MA, Garreaud RD (2009) Formation of cristobalite nanofibers during explosive volcanic eruptions. Geology 37:435-438. https://doi.org/10.1130/G25457A.1

Rojas-Ramos M, Catalan-Vazquez M, Pozzo AL, Garcia-Ojeda E, Villalba-Caloca J, Perez-Neria J (2001) A seven month prospective study of the respiratory effects of exposure to ash from Popocatepetl volcano, Mexico. Environ Geochem Health 23:383-396. https://doi.org/10.1023/A:1012244311557

Schmidt A, Ostro B, Carslaw KS, Wilson M, Thordarson T, Mann GW, Simmons AJ (2011) Excess mortality in Europe following a future Laki-style Icelandic eruption. Proceedings of the National Academy of Sciences 108:15710-15715. https://doi. org/10.1073/pnas.1108569108

Schmidt A, Leadbetter S, Theys N et al. (2015) Satellite detection, long-range transport and air quality impacts of volcanic sulfur dioxide from the 2014-15 flood lava eruption at Bárðarbunga (Iceland). J Geophys Res Atmos JD023638. https://doi.org/10. 1002/2015JD023638

Shimizu Y, Dobashi K, Hisada T, Ono A, Todokoro M, Iijima H, Utsugi M, Kakegawa S, Iizuka K, Ishizuka T, Morikawa A, Mori M (2007) Acute impact of volcanic ash on asthma symptoms and treatment. Int J Immunopathol Pharmacol 20:9-14. https://doi. org/10.1177/03946320070200S203

Shiozawa M, Lefor AK, Sata N, Yasuda Y, Nagai H (2018) Effects of the Miyakejima volcano eruption on public health. Int J Crit Care Emerg Med 4:040. https://doi.org/10.23937/2474-3674/1510040

Shojima J, Ikushima S, Ando T, Mochida A, Yanagawa T, Takemura T, Oritsu M (2006) A case of volcanic ash lung: report of a case. Nihon Kokyuki Gakkai Zasshi 44:192-196

Steinle S, Sleeuwenhoek A, Mueller W, Horwell CJ, Apsley A, Davis A, Cherrie JW, Galea KS (2018) The effectiveness of respiratory protection worn by communities to protect from volcanic ash inhalation. Part II: Total inward leakage tests. Int J Hyg Environ Health 221:977-984. https://doi.org/10.1016/j.ijheh.2018.03.011

Stewart C, Johnston DM, Leonard GS, Horwell CJ et al (2006) Contamination of water supplies by volcanic ashfall: a literature review and simple impact modelling. J Volcanol Geotherm Res 158:296-306. https://doi.org/10.1016/j.jvolgeores.2006.07.002

Stewart C, Cronin SJ, Wilson TM, Clegg S (2014) Analysis of Mt Sinabung volcanic ash: implications for animal health. GNS Science Report 2014/65; Available as free download from http:// shop.gns.cri.nz/sr_2014-065-pdf/

Stewart C, Damby DE, Tomašek I, Horwell CJ, Plumlee G, Armienta MA, Ruiz Hinojosa MG, Appleby M, Delmelle P, Cronin S, Ottley CJ, Oppenhemier C, Morman S (2020) Assessment of leachable elements in volcanic ashfall: a review and evaluation of a standardized protocol for ash hazard characterization. Journal of Volcanology and Geothermal Research 392:106756. https://doi. org/10.1016/j.jvolgeores.2019.106756

Stewart C, Rosenberg MD, Kilgour GN (2021) Ash leachate characteristics of the 27 April 2016 and 13 September 2016 eruptions of Whakaari / White Island volcano. Lower Hutt (NZ): GNS Science. 15 p. (GNS Science report; 2020/39)

Tam E, Miike R, Labrenz S, Sutton AJ, Elias T, Davis J, Chen Y-L, Tantisira K, Dockery D, Avol E (2016) Volcanic air pollution over the Island of Hawai'i: emissions, dispersal, and composition. Association with respiratory symptoms and lung function in Hawai'i Island school children. Environment International 92-93:543-552. https://doi.org/10.1016/j.envint.2016.03.025
Tesone AI, Vitar RML, Tau J, Maglione GA, Llesuy S, Tasat DR, Berra A (2018) Volcanic ash from Puyehue-Cordón Caulle Volcanic Complex and Calbuco promote a differential response of proinflammatory and oxidative stress mediators on human conjunctival epithelial cells. Environmental Research 167:87-97. https:// doi.org/10.1016/j.envres.2018.07.013

Tomašek I, Horwell CJ, Damby DE, Barošová H, Geers C, Petri-Fink A, Rothen-Rutishauser B, Clift MJD (2016) Combined exposure of diesel exhaust particles and respirable Soufrière Hills volcanic ash causes a (pro-)inflammatory response in an in vitro multicellular epithelial tissue barrier model. Part Fibre Toxicol 13:67. https://doi.org/10.1186/s12989-016-0178-9

Tomašek I, Horwell CJ, Bisig C, Damby DE, Comte P, Czerwinski J, Petri-Fink A, Clift MJD, Drasler B, Rothen-Rutishauser B (2018) Respiratory hazard assessment of combined exposure to complete gasoline exhaust and respirable volcanic ash in a multicellular human lung model at the air-liquid interface. Environ Pollut 238:977-987. https://doi.org/10.1016/j.envpol.2018.01.115

Tomašek I, Damby DE, Horwell CJ, Ayris PM, Delmelle P, Ottley CJ, Cubillas P, Casas AS, Bisig C, Petri-Fink A (2019) Assessment of the potential for in-plume sulphur dioxide gas-ash interactions to influence the respiratory toxicity of volcanic ash. Environ Res 179:108798. https://doi.org/10.1016/j.envres.2019.108798

Tomašek I, Damby DE, Andronico D, Baxter PJ, Boonen I, Claeys P et al (2021) Assessing the biological reactivity of organic compounds on volcanic ash: implications for human health hazard. Bull Volcanol 83:30. https://doi.org/10.1007/ s00445-021-01453-4

Tomašek I, Damby DE, Stewart C, Horwell CJ, Plumlee G, Ottley CJ, Delmelle P, Morman S, El Yazidi S, Claeys P, Kervyn M, Elskens M, Leermakers M (2021b) Development of a simulated lung fluid leaching method to assess the release of potentially toxic elements from volcanic ash. Chemosphere 278:130303. https://doi.org/10.1016/j.chemosphere.2021.130303

Trisnawati I, Budiono E, Sumardi S, Setiadi A (2015) Traumatic inhalation due to Merapi Volcanic Ash. Acta Medica Indonesiana 47:3

Viane C, Bhugwant C, Sieja B, Staudacher T, Demoly P (2009) Comparative study of the volcanic gas emissions and the hospitalizations for asthma of the Reunion Island population between 2005 and 2007. Revue Française d'Allergologie 49:346-351. https:// doi.org/10.1016/j.reval.2009.02.010

Webb E, Stewart C, Sami E, Kelsey S, Fairbairn Dunlop P, Dennison E (2021) Variability of naturally occurring fluoride in diverse community drinking water sources, Tanna Island, Vanuatu. Water, Hygiene and Sanitation for Development 11:591-599. https:// doi.org/10.2166/washdev.2021.270

Whitty RCW, Ilyinskaya E, Mason E, Wieser PE, Liu EJ, Schmidt A, Roberts T, Pfeffer MA, Brooks B, Mather TA, Edmonds M, Elias T, Schneider DJ, Oppenheimer C, Dybwad A, Nadeau PA, Kern $\mathrm{C}$ (2020) Spatial and temporal variations in $\mathrm{SO}_{2}$ and $\mathrm{PM}_{2.5}$ levels around Kīlauea Volcano, Hawai'i During 2007-2018. Front Earth Sci 8. https://doi.org/10.3389/feart.2020.00036

Wilson TM, Cole JW, Stewart C, Cronin S, Johnston DM (2011) Ash storms: impacts of wind-remobilised volcanic ash on rural communities and agriculture following the 1991 Hudson eruption, southern Patagonia, Chile. Bulletin of Volcanology 73:223-239. https://doi.org/10.1007/s00445-010-0396-1

Wilson T, Stewart C, Bickerton H, Baxter P, Outes AV, Villarosa G, Rovere E (2013) Impacts of the June 2011 Puyehue-Cordón Caulle volcanic complex eruption on urban infrastructure, agriculture and public health. GNS Science Report 2012/20, p 88. https://www.gns.cri.nz/static/pubs/2012/SR\%202012-020\% 20Print\%20Copy.pdf

Witham C, Barsotti S, Dumont S, Oddson B, Sigmundsson F (2020) Practising an explosive eruption in Iceland: outcomes from a 
European exercise. J Appl Volcanol 9:1. https://doi.org/10.1186/ s13617-019-0091-7

World Health Organization (2013) Regional Office for Europe. Review of evidence on health aspects of air pollution: REVIHAAP Project Technical Report, p 302
Wygel CM, Peters SC, McDermott JM, Sahagian DL (2019) Bubbles and dust: experimental results of dissolution rates of metal salts and glasses from volcanic ash deposits in terms of surface area, chemistry, and human health impacts. GeoHealth 3:338-355. https://doi.org/10.1029/2018GH000181

\title{
Authors and Affiliations
}

\author{
Carol Stewart ${ }^{1}\left(\mathbb{D} \cdot\right.$ David E. Damby $^{2}\left(\mathbb{D} \cdot\right.$ Claire J. Horwell $^{3}$ - Tamar Elias $^{4}\left(\mathbb{D} \cdot\right.$ Evgenia llyinskaya $^{5}(\mathbb{D} \cdot$

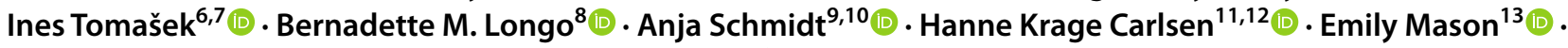 \\ Peter J. Baxter ${ }^{14}$ (D) Shane Cronin ${ }^{15}$ (D) . Claire Witham ${ }^{16}$ (D) \\ David E. Damby \\ ddamby@usgs.gov \\ Claire J. Horwell \\ claire.horwell@durham.ac.uk \\ Tamar Elias \\ telias@usgs.gov \\ Evgenia Ilyinskaya \\ e.ilyinskaya@leeds.ac.uk \\ Ines Tomašek \\ ines.tomasek@uca.fr \\ Bernadette M. Longo \\ longo@unr.edu \\ Anja Schmidt \\ as2737@cam.ac.uk \\ Hanne Krage Carlsen \\ hanne.krage.carlsen@amm.gu.se \\ Emily Mason \\ em572@cam.ac.uk \\ Peter J. Baxter \\ pjb21@medschl.cam.ac.uk \\ Shane Cronin \\ s.cronin@auckland.ac.nz \\ Claire Witham \\ claire.witham@metoffice.gov.uk \\ 1 School of Health Sciences, Massey University, PO Box 756, \\ Wellington 6021, New Zealand \\ 2 U.S. Geological Survey, Volcano Science Center, \\ Menlo Park, CA, USA \\ 3 Institute of Hazard, Risk \& Resilience, Department \\ 4 U.S. Geological Survey, Hawaiian Volcano Observatory, \\ Hilo, HI, USA \\ 5 School of Earth and Environment, University of Leeds, \\ Leeds, UK \\ 6 Laboratoire Magmas et Volcans (LMV), CNRS, IRD, OPGC, \\ Université Clermont Auvergne, Clermont-Ferrand, France \\ 7 Institute of Genetic Reproduction and Development (iGReD), \\ Translational Approach to Epithelial Injury and Repair Team, \\ CNRS UMR 6293, INSERM U1103, Université Clermont \\ Auvergne, Clermont-Ferrand, France \\ 8 Orvis School of Nursing, University of Nevada, Reno, NV, \\ USA \\ 9 Centre for Atmospheric Science, Department of Chemistry, \\ University of Cambridge, Cambridge, UK \\ 10 Department of Geography, University of Cambridge, \\ Cambridge, UK \\ 11 Department Environment and Natural Resources, University \\ of Iceland, Reykjavík, Iceland \\ 12 Department of Occupational and Environmental Medicine, \\ School of Public Health and Community Medicine, \\ Sahlgrenska Academy, Gothenburg University, Gothenburg, \\ Sweden \\ 13 Department of Earth Sciences, University of Cambridge, \\ Downing Street, Cambridge, Cambridgeshire CB2 3EQ, UK \\ 14 Department of Public Health and Primary Care, \\ University of Cambridge, Downing Street, Cambridge, \\ Cambridgeshire CB2 3EQ, UK \\ 15 School of Environment, University of Auckland, Private Bag \\ 92019, Auckland 1142, New Zealand \\ 16 Met Office, FitzRoy Road, Exeter EX1 3PB, UK
} of Earth Sciences, Lower Mountjoy, Durham University, Durham DH1 3LE, UK 